\title{
man \\ Mitigation of Salinity Stress Effects on Broad Bean Productivity Using Calcium Phosphate Nanoparticles Application
}

\author{
Amira K. Nasrallah ${ }^{1}$, , Ahmed A. Kheder ${ }^{2}$, Maimona A. Kord ${ }^{1, *}$, Ahmed S. Fouad ${ }^{1}\left(\mathbb{D}\right.$, Mohamed M. El-Mogy $^{3}$ \\ and Mohamed A. M. Atia ${ }^{4, *}$ (D) \\ 1 Department of Botany and Microbiology, Faculty of Science, Cairo University, Giza 12613, Egypt; \\ anasrallah@sci.cu.edu.eg (A.K.N.); ahmedsfouad@yahoo.com (A.S.F.) \\ 2 Virus and Phytoplasma Research Department, Plant Pathology Research Institute, \\ Agricultural Research Center, Giza 12619, Egypt; ahmedkheder@hotmail.com \\ 3 Vegetable Crops Department, Faculty of Agriculture, Cairo University, Giza 12613, Egypt; \\ elmogy@agr.cu.edu.eg \\ 4 Genome Mapping Department, Agricultural Genetic Engineering Research Institute (AGERI), \\ Agricultural Research Center (ARC), Giza 12619, Egypt \\ * Correspondence: kord@sci.cu.edu.eg (M.A.K.); matia@ageri.sci.eg (M.A.M.A.); \\ Tel.: +20-01223139977 (M.A.K.); +20-1000164922 (M.A.M.A.)
}

check for

updates

Citation: Nasrallah, A.K.; Kheder, A.A.; Kord, M.A.; Fouad, A.S.; El-Mogy, M.M.; Atia, M.A.M. Mitigation of Salinity Stress Effects on Broad Bean Productivity Using Calcium Phosphate Nanoparticles Application. Horticulturae 2022, 8, 75. https://doi.org/10.3390/ horticulturae 8010075

Academic Editor: Azam Noori

Received: 5 December 2021

Accepted: 11 January 2022

Published: 14 January 2022

Publisher's Note: MDPI stays neutral with regard to jurisdictional claims in published maps and institutional affiliations.

Copyright: (C) 2022 by the authors. Licensee MDPI, Basel, Switzerland. This article is an open access article distributed under the terms and conditions of the Creative Commons Attribution (CC BY) license (https:// creativecommons.org/licenses/by/ $4.0 /)$

\begin{abstract}
Water salinity is one of the major abiotic stresses, and the use of saline water for the agricultural sector will incur greater demand in the coming decades. Recently, nanoparticles (NPs) have been used for developing numerous plant fertilizers as a smart and powerful form of material with dual action that can alleviate the adverse effects of salinity and provide the plant with more efficient nutrient forms. This study evaluated the influence of calcium phosphate NPs (CaP-NPs) as a soil fertilizer application on the production and bioactive compounds of broad bean plants under salinity stress. Results showed that salinity had deleterious effects on plant yield with $55.9 \%$ reduction compared to control. On the other hand, CaP-NPs dramatically improved plant yield by $30 \%$ compared to conventional fertilizer under salinity stress. This improvement could be attributed to significantly higher enhancement in total soluble sugars, antioxidant enzymes, proline content, and total phenolics recorded use of nano-fertilizer compared to conventional use under salt stress. Additionally, nano-fertilizer reflected better mitigatory effects on plant growth parameters, photosynthetic pigments, and oxidative stress indicators (MDA and $\mathrm{H}_{2} \mathrm{O}_{2}$ ). Therefore, our results support the replacement of traditional fertilizers comprising $\mathrm{Ca}^{2+}$ or $\mathrm{P}$ with $\mathrm{CaP}-$ nano-fertilizers for higher plant productivity and sustainability under salt stress.
\end{abstract}

Keywords: salt stress; nano-fertilizer; calcium phosphate; antioxidant enzymes; Vicia faba L.; yield

\section{Introduction}

Broad bean, also known as broad beans (Vicia faba L.), is the fifth most crucial Fabaceae crop after pea, chickpea, common bean, and lentil [1]. According to FAOSTAT (2019), it is cultivated worldwide over 2.6 million hectares (has) with an annual production of 5.4 million tons. The importance of this leguminous crop arises from its high protein content (27-40\%), carbohydrate (50-60\%), minerals, and vitamins [2]. Furthermore, it is a good source of L-3,4-dihydroxyphenylalanine (L-DOPA), a precursor of a drug used to treat Parkinson's disease [1]. In addition, the broad bean plant plays a role in agricultural sustainability through nitrogen-fixing capability, improving crop productivity [3].

Globally, salinity is a major abiotic stress that severely affects crop plant growth and development from seed germination to harvest [4]. As a result, it reduces $30 \%$ of global food production [5]. At a global scale, it is estimated that one billion ha is affected by soil salinization increases at 2 million ha per year [6]. More than $7 \%$ of total land and about $20 \%$ of arable lands are harmed by salinity, particularly in arid and semi-arid regions such 
as Egypt [7]. Furthermore, most of world arable lands $(>50 \%)$ are predicted to be salinized by 2050 [8].

Salinity affects all the physiological processes in the plant, such as photosynthesis, protein synthesis, respiration, and lipid metabolism [9]. The initial effect of salt stress in plants is to reduce leaf surface expansion rate that may be completely stopped with a subsequent significant reduction in shoot growth [10]. Adverse effects of salinity on plant growth result from osmotic stress and ionic toxicity [11]. Sodium and chloride toxicity induces not only nutritional disorders but also causes physiological drought by lowering the osmotic potential of the soil solutions [12] that stimulate the accumulation of compatible solutes including soluble sugars and proline enabling water absorption [13].

High concentrations of sodium ions $\left(\mathrm{Na}^{+}\right)$leads to the excessive production of reactive oxygen species (ROS) as superoxide ions $\left(\mathrm{O}_{2}{ }^{\bullet-}\right)$, hydrogen peroxide $\left(\mathrm{H}_{2} \mathrm{O}_{2}\right)$, hydroxyl radical $\left(\mathrm{OH}^{-}\right)$, and singlet oxygen $\left({ }^{1} \mathrm{O}_{2}\right)$ in plant cells that are associated with membrane damage, lipid peroxidation, nutrient imbalance, altered levels of growth regulators, enzymatic, and metabolic disorder harming photosynthesis and ultimately plant death [14].

As a defense response, plants accumulate some compatible solutes, such as proline, sugars, amino acids, and proteins inside vacuoles [15]. These solutes are involved in osmotic regulation in plant cells, which maintain cellular homeostasis [16].

In addition, oxidative stress provokes and orchestrates enzymatic and non-enzymatic mechanisms to scavenge the accumulated ROS [17]. Superoxide dismutase (SOD) is the first defense line against oxidative damage [18]. It scavenges $\left(\mathrm{O}_{2}{ }^{\bullet-}\right)$ by its dismutation into molecular oxygen and $\mathrm{H}_{2} \mathrm{O}_{2}$ [19]. Several enzymes detoxify $\mathrm{H}_{2} \mathrm{O}_{2}$ in plant cells, such as catalase (CAT) which is responsible for converting it into $\mathrm{H}_{2} \mathrm{O}$ and $\mathrm{O}_{2}$ [20], and peroxidase (POX) by the oxidation of various substrates as guaiacol and pyrogallol [21]. At the same time, metabolic processes are directed towards biosynthetic pathways that consume reduction equivalents. Consequently, the biosynthesis of reduced compounds, including phenolics and flavonoids, is enhanced [22].

Calcium and phosphorus are essential macronutrients for plant metabolic processes and vital macromolecules. They are documented to alleviate the harmful effects of soil salinization on tomato [23], rice [24], sweetsop [25], and common bean [26]. However, excessive $\mathrm{P}$ and $\mathrm{Ca}$ fertilizers use causes many problems such as micronutrient imbalance, leaching, groundwater contamination, and eutrophication $[27,28]$. To limit these environmental problems, raise agricultural yield, and improve plant nutrient use efficiency for sustainable global development, novel fertilizer manufacture and application approaches are required.

Nanoparticles (NPs) are defined as particles with a size of 1 to $100 \mathrm{~nm}$ at least in one dimension. Compared to bulk materials, they can positively change physio-chemical characteristics, as their larger surface area makes their solubility and surface reactivity usually higher [29].

Application of nanoparticles can alleviate the injurious impact of salt stress through increasing the uptake of $\mathrm{K}^{+}$; decreasing the $\mathrm{Na}^{+}$ion toxicity; regulating ion balance; activating the antioxidative defense system; improving in membrane stability index; increasing the contents of the compatible solutes and pigments, in addition to increasing stomatal conductance as well as leaf water content [30].

Therefore, NPs are widely used to enhance salt tolerance in many field crops. Several studies have reported the salt-alleviating effect of various NPs such as nano-silicon in tomato [31], $\mathrm{CeO}_{2}-\mathrm{NPs}$ [32], and $\mathrm{Zn}-\mathrm{ONPs}$ [33] in Brassica napus. Further studies have reported growth-promoting silica NPs on lupin and wheat [34], and $\mathrm{Fe}_{2} \mathrm{O}_{3}-\mathrm{NPs}$ on soybean [35].

Recently, Rane et al. [36] reported that CaP-NPs promote growth and root maturation in maize plants. However, there are limited reports on the role of CaP-NPs in mitigating salt stress effects on plants. Therefore, we hypothesized that the use of CaP-NPs fertilizer is more effective than the corresponding conventional fertilizer and it also reduces the pollution in soil and enhances crop production under saline conditions. 
Therefore, the present study aimed to evaluate the potential use of CaP-NPs to mitigate the salinity stress in Vicia faba at the level of agro-physiological traits.

\section{Materials and Methods}

\subsection{Plant Material and Growth Conditions}

Seeds of broad bean (Vicia faba cv. Sakha 1) were surface sterilized in $1 \% \mathrm{NaClO}$ for $2 \mathrm{~min}$ and then washed three times with sterilized distilled water. Sterilized seeds were sown in plastic pots ( $30 \mathrm{~cm}$ in diameter) filled with a mixture of sand, clay, and peat moss in 1:1:1 $(v / v / v)$. Thirty days after sowing (DAS), vegetates were thinned to three uniform plants per pot, and pots were divided into six groups and arranged in randomized complete block design with three replicates per treatment under the same growth conditions.

\subsection{Transmission Electron Microscope (TEM)}

The CaP-NPs (containing calcium and phosphorous at $38.76 \%$ and $19.97 \%(\mathrm{~m} / \mathrm{m})$, respectively) used in this study were purchased from NanoTech Co., Cairo, Egypt. Based on transmission electron microscopy (JEM-1400 TEM, JOEL, Peabody, MA, USA), particles were spherical with a diameter of 6.41 to $11.3 \mathrm{~nm}$ (Figure 1). The experimental solution was prepared before use by suspending dry CaP-NPs powder in double-distilled water then sonication at $100 \mathrm{~W}$ and $30 \mathrm{kHz}$ for $30 \mathrm{~min}$ to avoid particle aggregation.

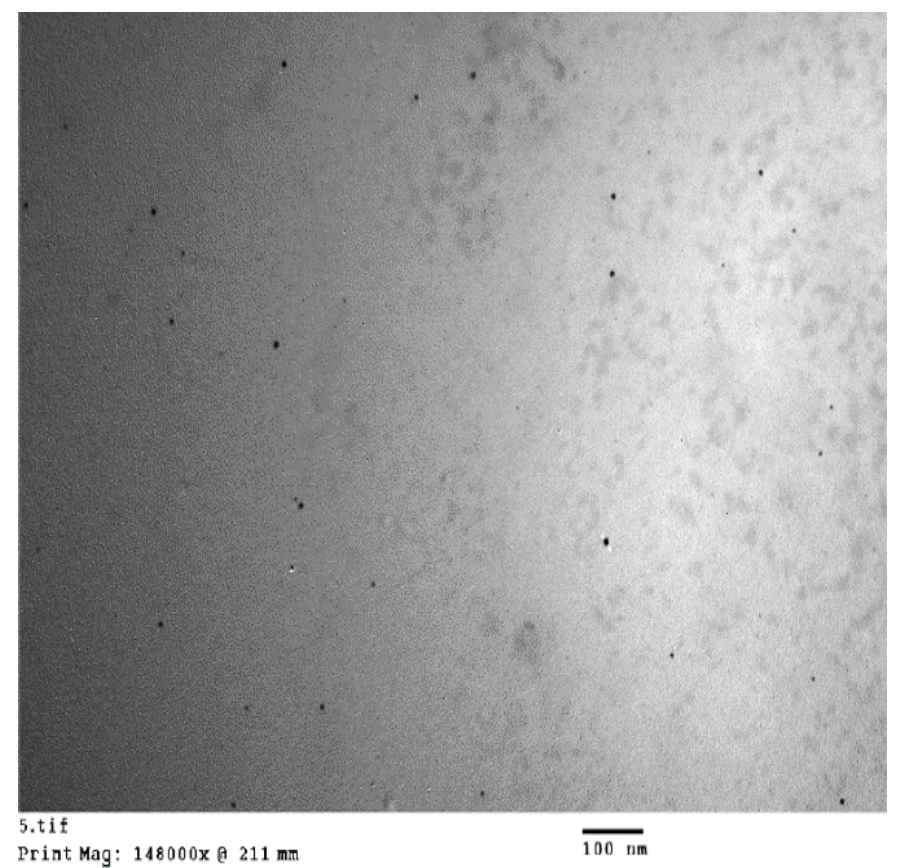

Figure 1. The TEM micrograph of CaP-NPs.

\subsection{Salinity and Fertilizer Treatments}

Based on a pilot experiment, the following treatments were applied through irrigation as illustrated in (Figure 2):

1 Tap water (Negative control)

2 Tap water supplemented with $\mathrm{CaP}\left(16 \mathrm{mg} \mathrm{L}^{-1}\right)$

3 Tap water supplemented with CaP-NPs $\left(16 \mathrm{mg} \mathrm{L}^{-1}\right)$

4 Tap water supplemented with $\mathrm{NaCl}(150 \mathrm{mM})$

5 Tap water supplemented with $\mathrm{CaP}\left(16 \mathrm{mg} \mathrm{L}^{-1}\right)$ and $\mathrm{NaCl}(150 \mathrm{mM})$

6 Tap water supplemented with CaP-NPs $\left(16 \mathrm{mg} \mathrm{L}^{-1}\right)$ and $\mathrm{NaCl}(150 \mathrm{mM})$ 


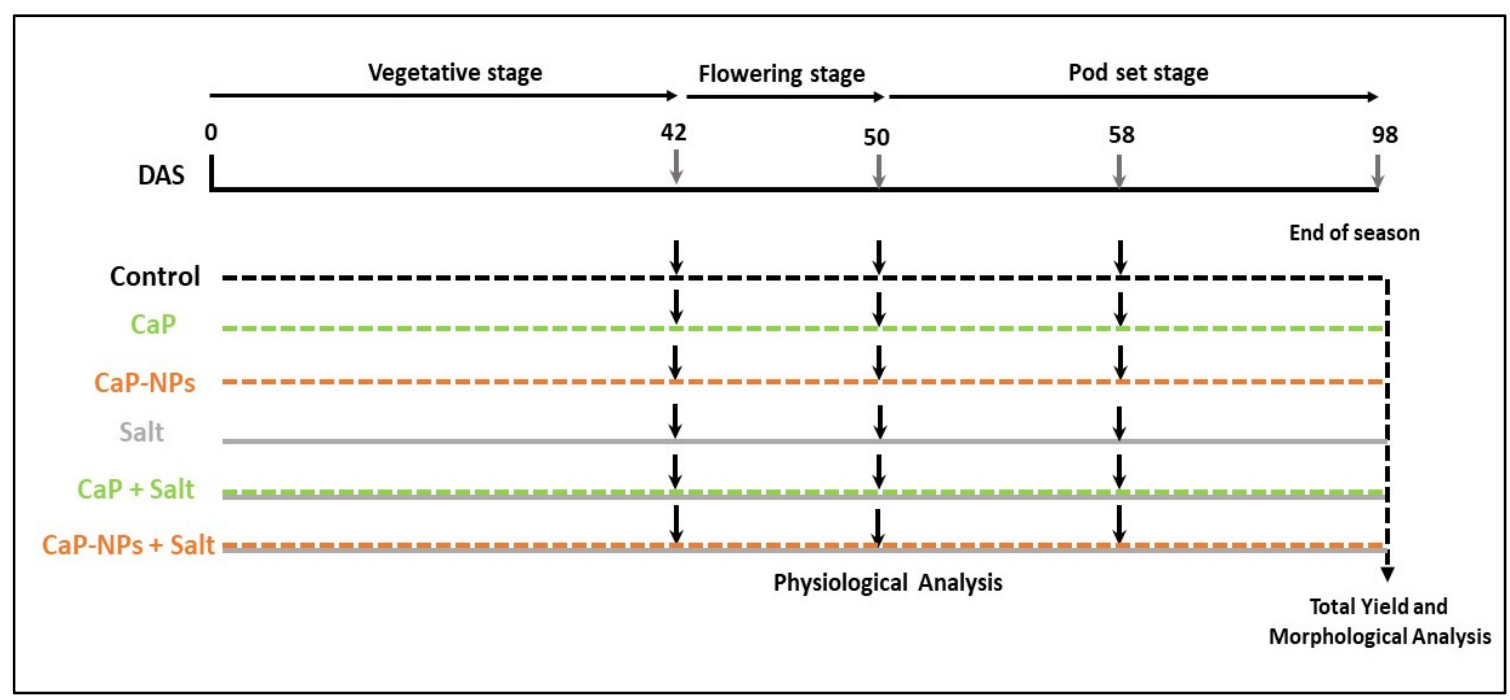

Figure 2. Scheme of the experimental setup. Horizontal lines represent different plant treatments: control, CaP, CaP-NPs, Salt, CaP-NPs + Salt, and CaP + Salt. Broad bean yield was harvested at the end of the experiment.

Each pot was irrigated with $250 \mathrm{~mL}$ solution every five days. For plants treated with $\mathrm{CaP}$ or CaP NPs, each plant received $18.13 \mathrm{mg}$ of the applied fertilizer during the entire growth cycle.

At 58 DAS (the end of February 2020), the plants were harvested for each treatment. Shoots were separated from roots using a sharp knife then weighed separately to obtain their fresh weights $(\mathrm{FW})$. Shoot height $(\mathrm{cm})$ of each plant was measured and leaf area $\left(\mathrm{cm}^{2}\right)$ was calculated using the comparison method. Dry weights of shoots and roots were recorded after oven-drying at $65^{\circ} \mathrm{C}$ until constant weight.

Leaf samples were collected from each treatment at the vegetative, flowering, and pod set stage $\left(42,50,58\right.$ DAS respectively) and stored at $-80^{\circ} \mathrm{C}$ for physiological analyses in fresh tissues. At the same time, other representative leaf samples were collected and dried at $65^{\circ} \mathrm{C}$ till constant weight and devoted to analyses in dry tissues. The plants' provided leaf samples were discarded after sampling, while the remaining plants were left until the end of the experiment (98 DAS) for yield-related data. First, pods of each plant were harvested and counted, and then the seeds were collected from the pods and weighed to calculate the average weight of 1000 seeds and total yield.

\subsection{Quantification of Total Chlorophyll and Carotenoids}

Frozen leaves tissue (20 mg) was ground in $2 \mathrm{~mL}$ ice-cold $80 \%(v / v)$ acetone as described by Merwad et al. [37]. The total chlorophyll content was measured in a 96-well microplate reader (Infinite 200 PRO, Tecan Group Ltd., Männedorf, Switzerland) at 662, 644, and carotenoid at $440.5 \mathrm{~nm}$ using MacKinney equations Sestak et al. [38].

\subsection{Determination of Osmolytes Content}

Total soluble sugars content of $10 \mathrm{mg}$ dry leaves was extracted in $1.5 \mathrm{~mL}$ of distilled water in a boiling water bath for $1 \mathrm{~h} \mathrm{[39]} \mathrm{and} \mathrm{quantified} \mathrm{using} \mathrm{anthrone-sulfuric} \mathrm{acid} \mathrm{colorimetry}$ at $630 \mathrm{~nm}$ [40] with glucose as a calibration standard. The free proline in the dry leaves was extracted and estimated according to the protocol outlined by Shabnam et al. [41]. It was extracted from $10 \mathrm{mg}$ of dry leaves using $1.5 \mathrm{~mL}$ of $3 \%(w / v)$ sulfosalicylic acid solution and estimated using $1.25 \%(w / v)$ ninhydrin reagent in a boiling water bath for $30 \mathrm{~min}$. Absorbance was measured at $508 \mathrm{~nm}$ against a water-reagent blank in a 96-well reader and compared with the proline standard curve. 


\subsection{Extraction and Assay of Antioxidant Enzymes}

Antioxidant enzymes were extracted according to Grace and Logan [42], where $100 \mathrm{mg}$ of frozen leaf tissue was powdered in liquid nitrogen and homogenized in $1 \mathrm{~mL}$ potassium phosphate buffer $(50 \mathrm{mM}, \mathrm{pH} 7.0)$ containing $4 \%(w / v) \mathrm{PVP}, 2 \%(v / v)$ glycerol and $0.1 \mathrm{mM}$ EDTA. Homogenates were centrifuged at $15,000 \times g$ for $30 \mathrm{~min}$ at $4{ }^{\circ} \mathrm{C}$ and the supernatants were used to analyze enzymes activities.

The peroxidase (POX, EC: 1.11.1.7) activity was assessed according to Lagrimini [43]. Briefly, $2.9 \mathrm{~mL}$ of the reaction mixture (50 mM phosphate buffer ( $\mathrm{pH}$ 7.0), $0.1 \mathrm{mM}$ EDTA, $30 \mathrm{mM} \mathrm{H}_{2} \mathrm{O}_{2}$, and $100 \mathrm{mM}$ Guaiacol) was added to $100 \mu \mathrm{L}$ of crude extract. The formation of tetraguaiacol was measured at $465 \mathrm{~nm}$ using the extinction coefficient $26.6 \mathrm{mM}^{-1} \mathrm{~cm}^{-1}$. The POX activity was expressed as $\mu \mathrm{mol}$ tetraguaiacol $\mathrm{mg}^{-1}$ protein $\mathrm{min}^{-1}$.

Catalase (CAT, EC: 1.11.1.6) activity was assayed by measuring the ability of the enzyme extract to decompose hydrogen peroxide $\left(\mathrm{H}_{2} \mathrm{O}_{2}\right)$ at room temperature by detecting the decrease in absorbance at $240 \mathrm{~nm}$ [44]. The reaction mixture was composed of $100 \mathrm{mM}$ potassium phosphate buffer ( $\mathrm{PH} \mathrm{7}$ ) and $25 \mathrm{mM} \mathrm{H}_{2} \mathrm{O}_{2}$. The reaction was started by adding $100 \mu \mathrm{L}$ crude extract in $3 \mathrm{~mL}$ total volume. A decrease in $\mathrm{H}_{2} \mathrm{O}_{2}$ content was calculated using the extinction coefficient $43.6 \mathrm{M}^{-1} \mathrm{~cm}^{-1}$. The results were expressed as $\mathrm{mmol} \mathrm{H}_{2} \mathrm{O}_{2} \mathrm{mg}^{-1}$ protein $\mathrm{min}^{-1}$.

Superoxide dismutase (SOD, EC: 1.15.1.1) activity was determined as described by Dhindsa et al. [45] depending on its ability to inhibit nitro blue tetrazolium (NBT) photoreduction. First, $10 \mu \mathrm{L}$ of enzyme extract was mixed with $200 \mu \mathrm{L}$ of reaction mixture composed of $75 \mu \mathrm{M}$ NBT, $60 \mu \mathrm{M}$ riboflavin, $13 \mathrm{mM}$ methionine, $0.1 \mathrm{mM}$ ethylenediaminetetraacetic acid (EDTA), and $50 \mathrm{mM}$ phosphate buffer $(\mathrm{pH}=7.8)$. Subsequently, the mixture was exposed to a $15 \mathrm{~W}$ fluorescent lamp for $10 \mathrm{~min}$ at a distance of $20 \mathrm{~cm}$ and then the reaction was stopped by covering the plate with a black cloth immediately. The absorbance was recorded at $560 \mathrm{~nm}$. One unit of SOD represents the amount of enzyme that inhibits the nitro blue tetrazolium photoreduction by $50 \%$ and expresses as enzyme unit $\mathrm{mg}^{-1}$ protein $\min ^{-1}$.

Total soluble protein content was determined in crude extract according to Lowry [46].

\subsection{Malondialdehyde and Hydrogen Peroxide Content}

Lipid peroxidation status was determined as malondialdehyde (MDA) level as described by Heath and Packer [47]. Briefly, $20 \mathrm{mg}$ of fresh leaves was homogenized in $500 \mu \mathrm{L}$ of $0.1 \%(w / v)$ trichloroacetic acid (TCA) at $4{ }^{\circ} \mathrm{C}$ then $50 \mu \mathrm{L}$ of the clear extract was incubated with $150 \mu \mathrm{L}$ of $0.5 \%(v / v)$ thiobarbituric acid (TBA) in $20 \%(w / v)$ TCA at $95{ }^{\circ} \mathrm{C}$ for $60 \mathrm{~min}$ to produce (TBA-MDA). The difference between specific and non-specific absorbance at 532 and $600 \mathrm{~nm}$, respectively, was used to quantify MDA based on the extinction coefficient of $155 \mathrm{mM}^{-1} \mathrm{~cm}^{-1}$.

Hydrogen peroxide $\left(\mathrm{H}_{2} \mathrm{O}_{2}\right)$ content in fresh leaves was determined as described by Junglee et al. [48]. Leaf tissue $(150 \mathrm{mg})$ was directly homogenized in an ice bath with $1 \mathrm{~mL}$ of extraction mixture containing $0.1 \%(w / v)$ TCA, $1 \mathrm{M} \mathrm{KI}$, and $10 \mathrm{mM}$ potassium phosphate buffer ( $\mathrm{pH}$ 5.8) for $10 \mathrm{~min}$. The clear extract was employed to directly estimate $\mathrm{H}_{2} \mathrm{O}_{2}$ at 390 based on the $\mathrm{H}_{2} \mathrm{O}_{2}$ standard curve.

\subsection{Total Phenolic Content}

Total phenolic content (TPC) was extracted from dry leaf material with $70 \%$ ethanol $(v / v)$ according to the method outlined by Sauvesty et al. [49]. Therefore, $50 \mu \mathrm{L}$ of the clear extract was used to estimate TPC according to Lowe [50], using a mixture of $100 \mu \mathrm{L}$ of $10 \%(v / v)$ Folin-Ciocalteu phenol reagent (LOBA CHEMIE PVT. Ltd., Mumbai, India) and $100 \mu \mathrm{L}$ of $20 \%(w / v)$ anhydrous sodium carbonate. The absorbance of the developed blue color was measured after $30 \mathrm{~min}$ at $650 \mathrm{~nm}$ and used to quantify TPC based on a gallic acid standard curve. 


\subsection{Total Flavonoids}

Total flavonoids were extracted from $15 \mathrm{mg}$ dried leaf tissues in $500 \mu \mathrm{L} \mathrm{80 \%}(v / v)$ methanol and estimated using Chang et al. [51] method. Briefly, $25 \mu \mathrm{L}$ of the supernatant was mixed with $150 \mu \mathrm{L}$ distilled water and $10 \mu \mathrm{L}$ of $3.75 \%$ sodium nitrite $\left(\mathrm{NaNO}_{2}\right)$, followed by $15 \mu \mathrm{L}$ of $10 \%$ Aluminum chloride $\left(\mathrm{AlCl}_{3}\right)$ after $6 \mathrm{~min}$. The absorbance was measured at $510 \mathrm{~nm}$ after further $5 \mathrm{~min}$ incubation with $50 \mu \mathrm{L}$ of $1 \mathrm{M} \mathrm{NaOH}$ and compared with the rutin standard curve.

\subsection{Statistical Analysis}

The measured parameters in all treatments were represented as the mean of 3 replicates with calculated standard error $( \pm \mathrm{SE})$. The mean values were compared through the Duncan multiple comparison test at the 5\% level of significance using SPSS 15 software. Person correlations between all measured traits were calculated using the same software. The correlations were represented as a matrix heatmap using MS Excel 2019.

\section{Results}

\subsection{Plant Growth and Yield}

Different growth parameters showed diverse responses following treatment with fertilizers (Figures 3-5). For CaP, root fresh weight, root dry weight, leaf area, and plant height increased reaching $117 \%, 130 \%, 126 \%$, and $119 \%$ of control, respectively, while the remaining growth parameters remained insignificantly affected. On the other hand, CaP-NPs treatment improved growth and yield expressed by shoot fresh weight, leaf area, plant height, pods weight/plant, and weight of 1000 seeds by $25 \%, 46 \%, 26 \%, 25 \%$ and $20 \%$ compared to control, respectively without significant effect for other parameters. Furthermore, compared with the corresponding results recorded for $\mathrm{CaP}$ treatments, leaf area and pod length reflected significantly better performance for $\mathrm{CaP}-\mathrm{NPs}$ while the remaining growth parameters showed no significant difference between the effects applied fertilizers.

Observing the control irrigated with tap water, salt stress significantly reduced all growth parameters and yield except shoot fresh and dry weight. Seed weight per plant was the most sensitive parameter for salt stress where it showed a $56 \%$ decrease compared with control. Both fertilizers alleviated the growth-retarding effects of salinity, which was more pronounced for nano-fertilizers observing root dry weight and seed yield per plant. Otherwise, both fertilizers showed insignificantly different mitigatory behavior.

\subsection{Carotenoids and Total Chlorophyll}

Compared with the control, carotenoids content decreased in response to $\mathrm{CaP}$ treatments in all stages (Figure 6A). However, CaP-NPs treatment was associated with significantly decreased carotenoids content during the pod set stage only. Exposure to salinity stress significantly decreased carotenoids by $22 \%, 19 \%$ and $20 \%$ during the vegetative, flowering, and pod set stages, respectively. Thus, the CaP-NPs nullified the inhibitory effect of salinity stress on carotenoid content at the flowering stage. Otherwise, both fertilizers failed to modify such effects significantly.

Applying CaP did not affect the green pigment content at the vegetative stage while it was associated with $21 \%$ and $23 \%$ inhibition, compared with the corresponding control at the last two stages (Figure 6B). On the other hand, CaP-NPs application was responsible for a $24 \%$ and $10 \%$ increase in chlorophyll content at the vegetative and flowering stages, respectively. However, nano-fertilizer decreased the green pigment to $80 \%$ of control at the pod set stage. Salinity stress was accompanied by a $22 \%, 34 \%$ and $31 \%$ decrease in chlorophyll content at vegetative, flowering, and pod set stages, respectively, compared with corresponding control (Figure 6B). Both fertilizers alleviated the harmful effects of salinity on chlorophyll content that was more obvious for CaP-NPs that eliminated such effects during vegetative and flowering stages. 

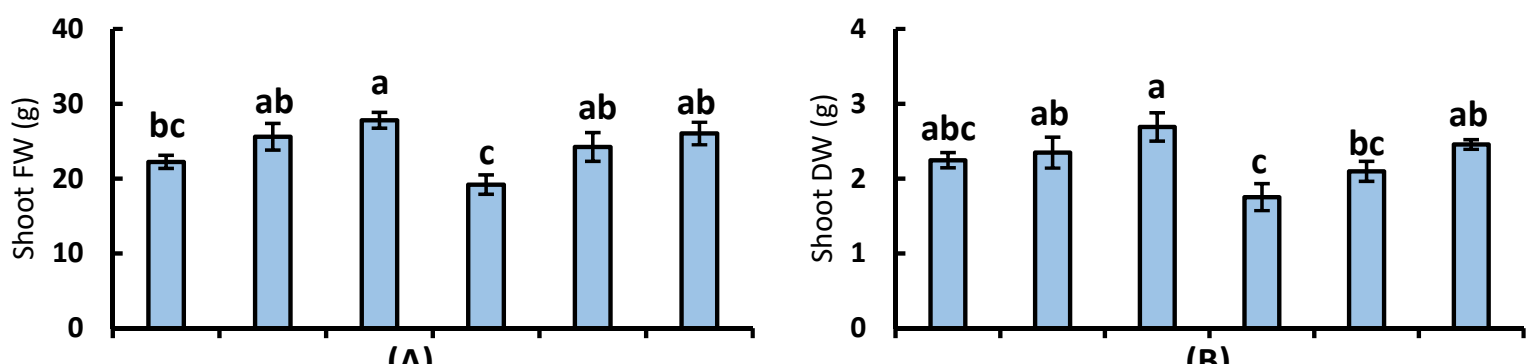

(B)
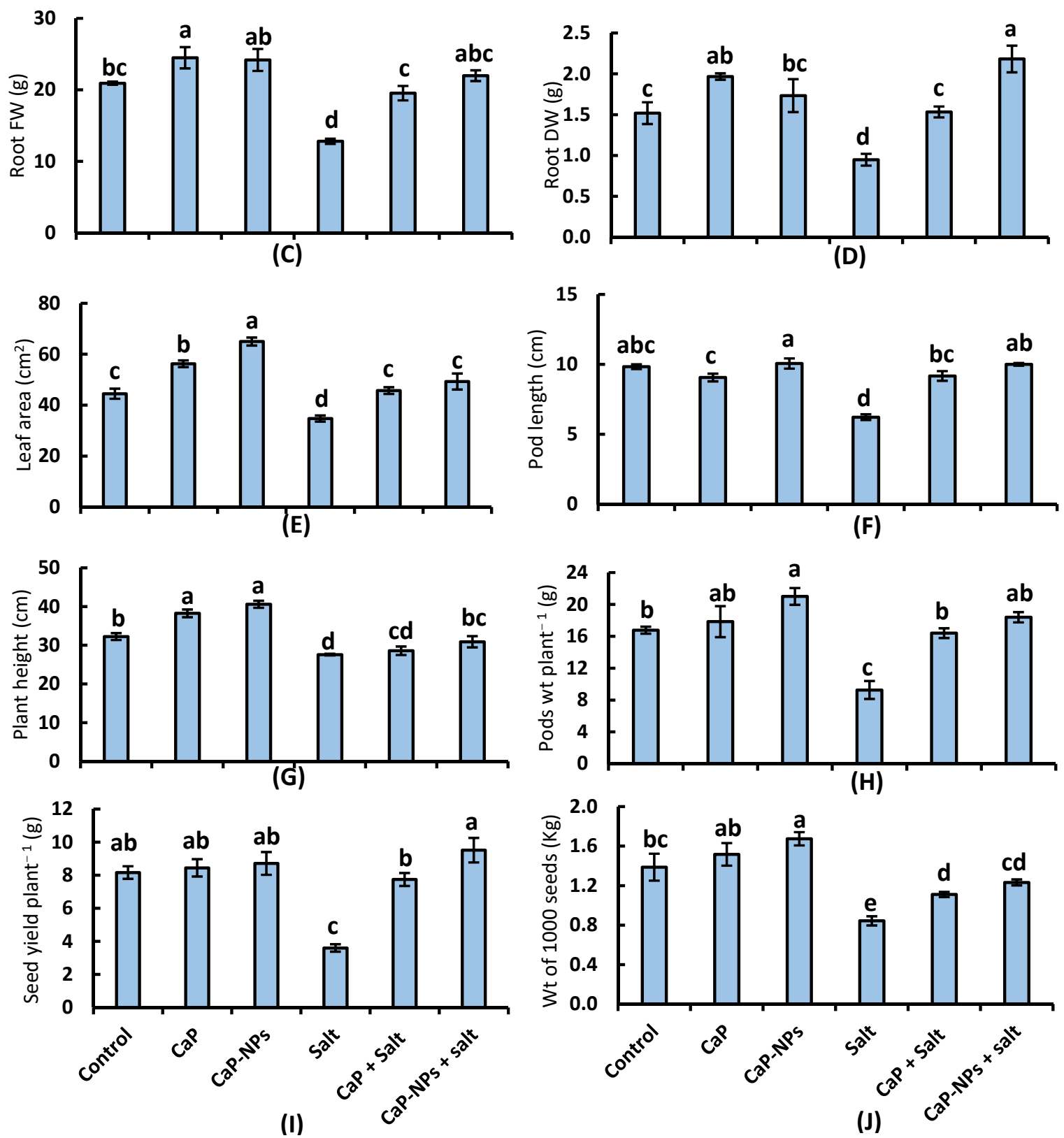

Figure 3. Effect of different treatments on (A) shoot fresh weight, (B) shoot dry weight, (C) root fresh weight, (D) root dry weight, (E) leaf area, (F) pod length, (G) plant height, (H) pods weight/plant, (I) seed yield/plant, and (J) weight of 1000 seeds. The same letters indicate no significant difference $(p<0.05)$ as analyzed by the Duncan test. Each value is the average of 3 replicates $\pm \mathrm{SE}$. 


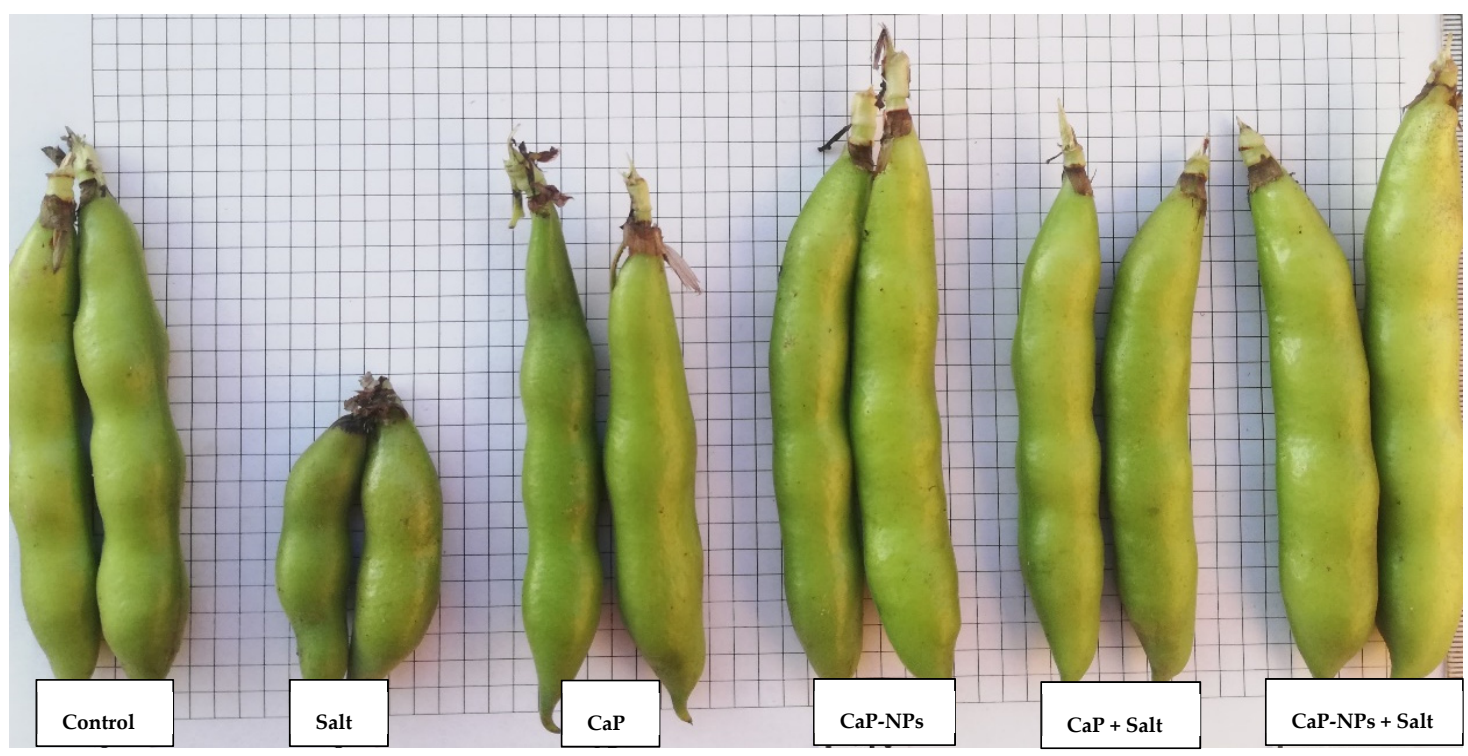

Figure 4. Effect of treatments on pods length $(\mathrm{cm})$ of broad bean under salt stress.

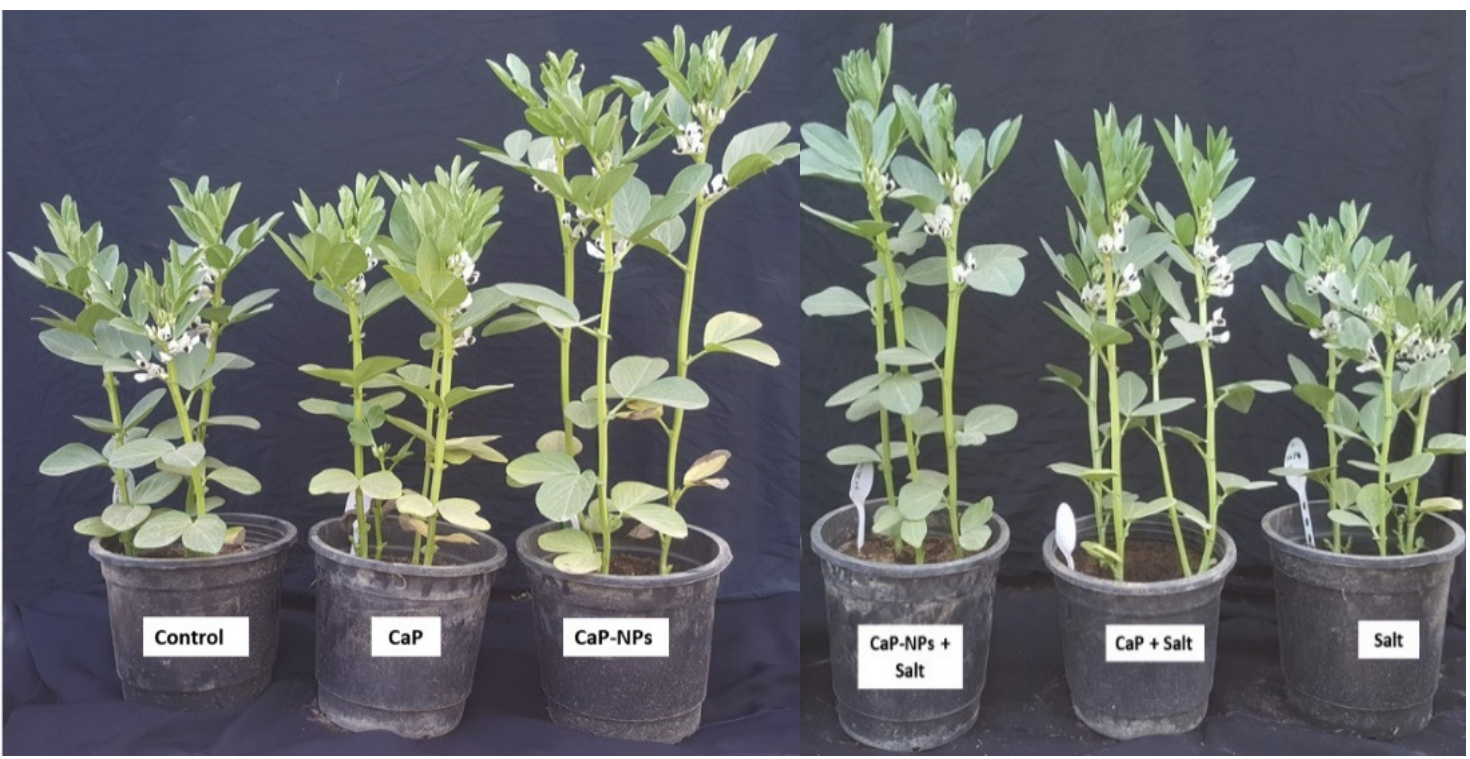

Figure 5. Effect of treatments on broad bean growth under salt stress.

Except for the significant decrease recorded following application of both fertilizers at the vegetative stage and application of the nano-fertilizer at the flowering stage, neither of CaP nor CaP-NPs modified carotenoids/total chlorophyll ratio was recorded for corresponding controls (Figure 6C). Salinity led to a $4 \%$ to $25 \%$ significant increase in carotenoids/total chlorophyll ratio at all stages, compared with tap water-irrigated controls. However, $\mathrm{CaP}$ treatment mitigated salt-induced elevations at the vegetative stage while the mitigatory effect of the other fertilizer extended to the flowering stage. Both CaP and CaP-NPs did not affect the ratio at the pod set stage. 
(A)

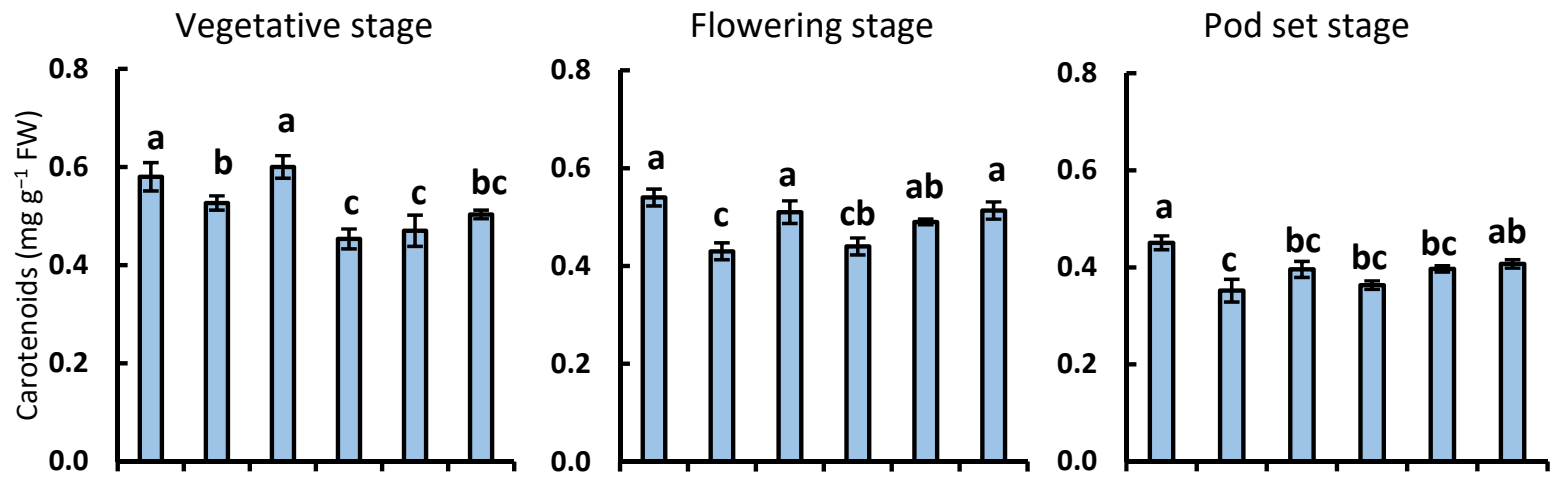

(B)
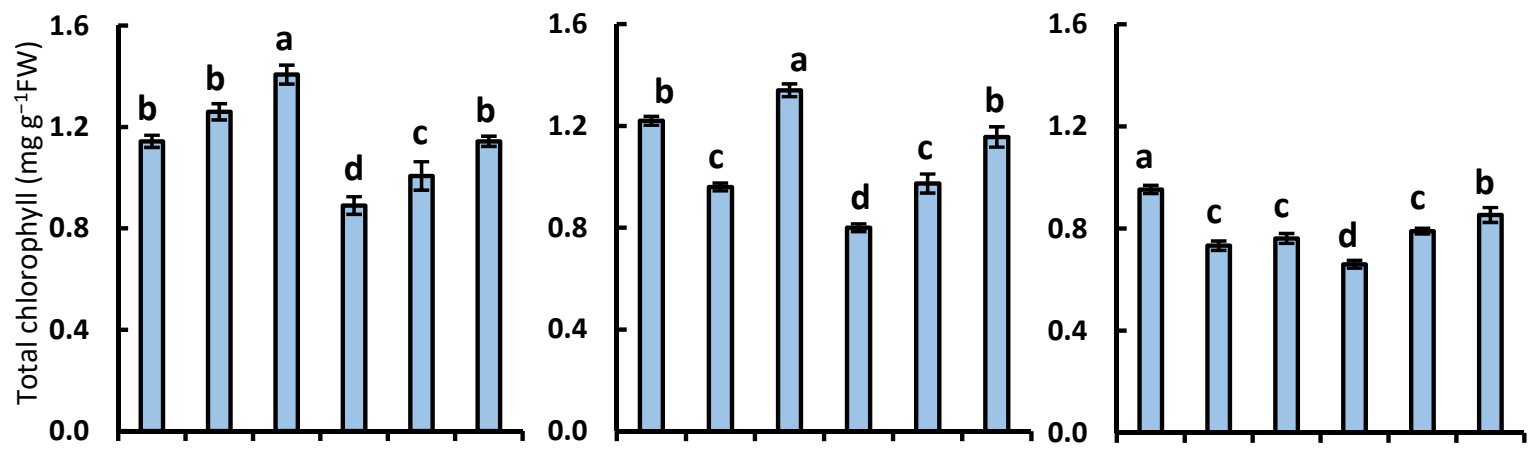

(C)
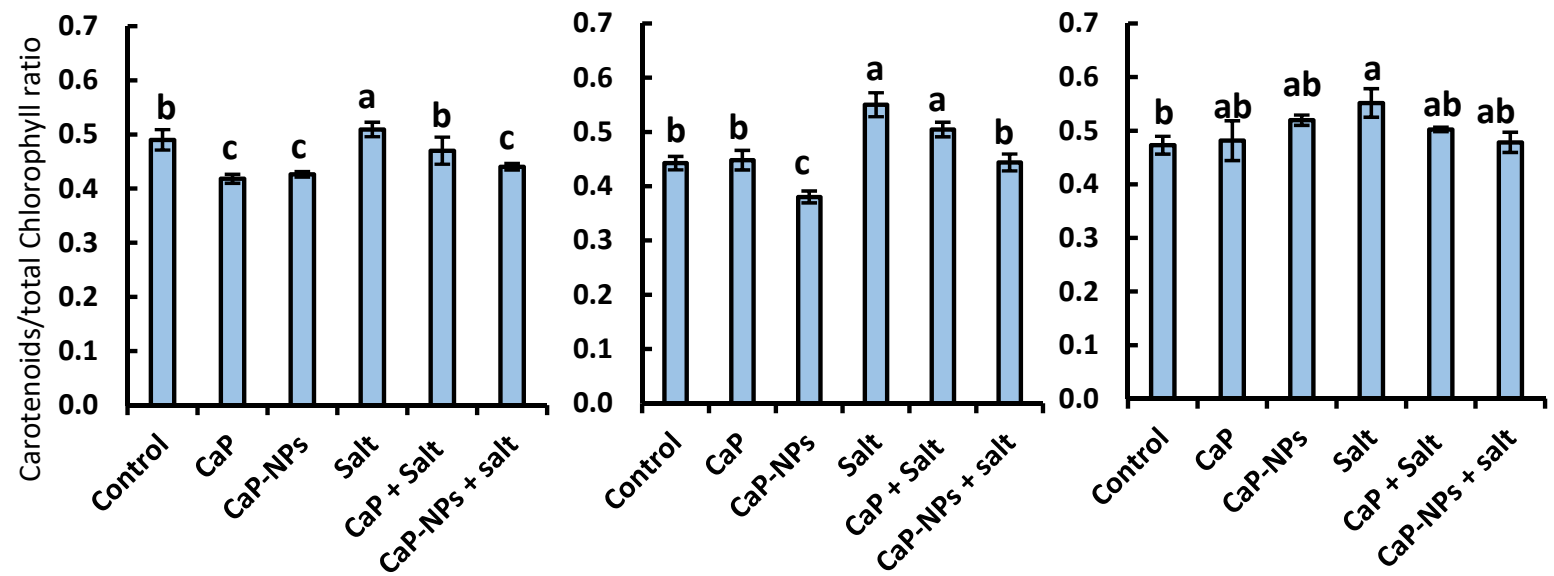

Figure 6. Effect of different treatments on (A) carotenoids, (B) total chlorophyll content, and (C) carotenoids/chlorophyll ratio of broad bean plants in 3 growth stages. The same letters indicate no significant difference $(p<0.05)$ as analyzed by the Duncan test. Each value is the average of 3 replicates $\pm \mathrm{SE}$.

\subsection{Proline Content and Total Soluble Sugar}

At the vegetative stage, the $\mathrm{CaP}$ treatment showed an increase in proline content by $24 \%$ of the corresponding control (Figure $7 \mathrm{~A}$ ). Meanwhile, the CaP-NPs treatment enhanced proline content by $12 \%, 30 \%$, and $24 \%$ at the vegetative, flowering, and pod set stage, respectively, compared with control (Figure 7A). Under $\mathrm{NaCl}$ stress, plants showed a marked accumulation in the interesting amino acid during all growth stages. Salt stressinduced proline accumulation was amplified by adding fertilizers at the vegetative stage that were more obvious when applying CaP-NPs. The amplification disappeared for CaP$\mathrm{NPs}$ and reversed for $\mathrm{CaP}$ at the flowering stage; thereafter, it similarly reversed for both fertilizers at the pod set stage. 
(A)

Vegetative stage

Flowering stage

Pod set stage
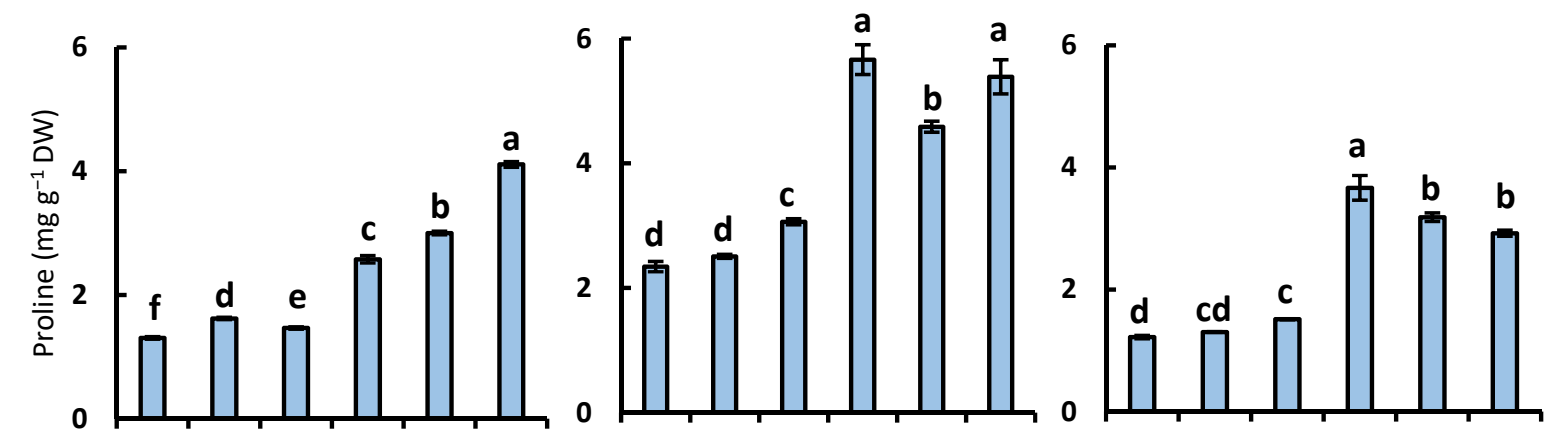

(B)
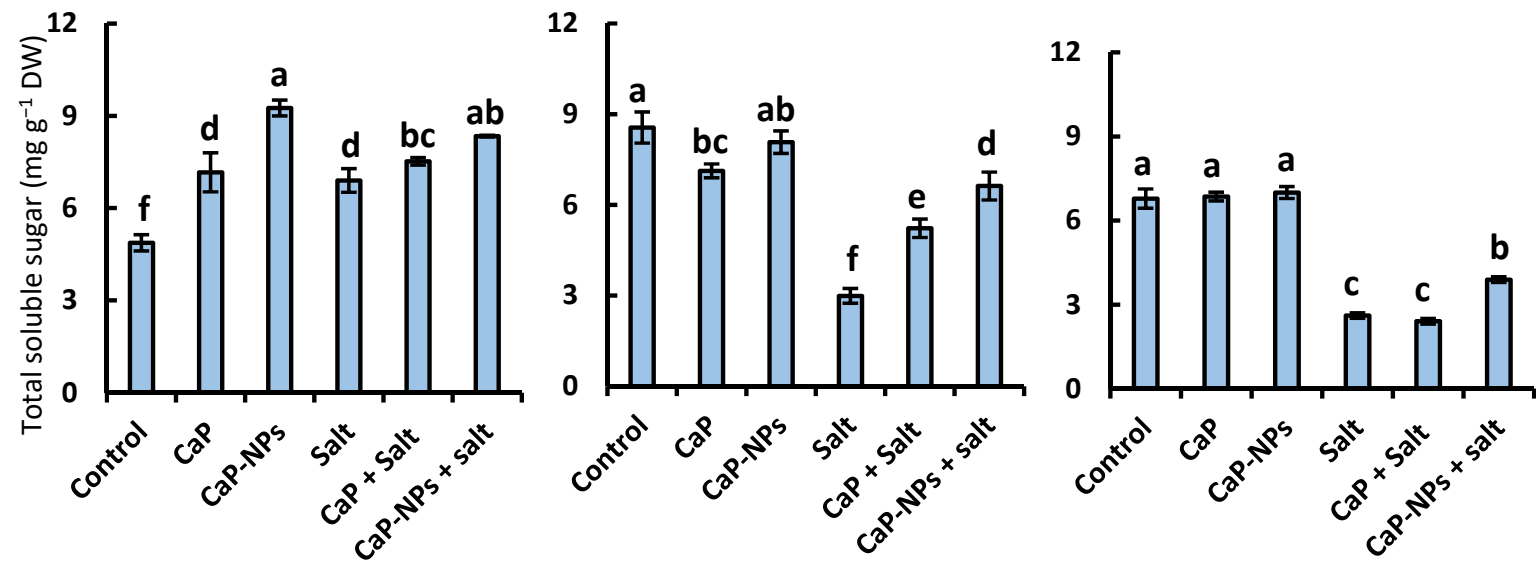

Figure 7. Effect of different treatments on (A) the proline content and (B) total soluble sugars of broad bean plants in 3 growth stages. The same letters indicate no significant difference $(p<0.05)$ as analyzed by the Duncan test. Each value is the average of 3 replicates \pm SE.

In the absence of salinity, $\mathrm{CaP}$ and $\mathrm{CaP}-\mathrm{NPs}$ increased total soluble sugar by $47 \%$ and $90 \%$, respectively, at the first developmental stage (Figure 7B). Except for the 17\% decrease following application of $\mathrm{CaP}$ at the middle stage, both fertilizers were accompanied with insignificant change, compared with the corresponding control, in total soluble sugars at the flowering and pod set stages. Under salt stress, the CaP-NPs induced increase in soluble sugar content by $71 \%, 23 \%$, and $43 \%$ at the vegetative, flowering, pod set stages, respectively, compared to non-stressed plants. Except at pod set stage applying $\mathrm{CaP}$, both fertilizers intensified salinity-provoked soluble sugar accumulation at all stages with better performance for nano-fertilizer.

\section{4. $\mathrm{MDA}$ Level and $\mathrm{H}_{2} \mathrm{O}_{2}$ Content}

Lipid peroxidation was expressed as an increase in MDA content in broad bean plants during the three developmental stages, as shown in (Figure 8A). CaP showed no harmful effect on membrane status at all developmental stages as indicated with a slight decrease in MDA content at the vegetative stage and no significant changes at the remaining stages. On the other hand, CaP-NPs treatment was accompanied without significant alteration in lipid peroxidation at the vegetative stage while it enhanced MDA accumulation at other stages. Salt stress stimulated MDA content reaching $144 \%, 196 \%$, and $159 \%$ of the corresponding control at vegetative, flowering, and pod set stages, respectively. Both fertilizers alleviated lipid peroxidation under salinity stress that was more pronounced applying CaP-NPs. 
(A)

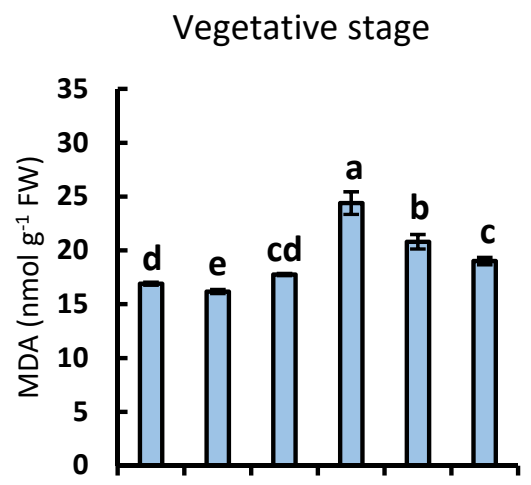

Flowering stage
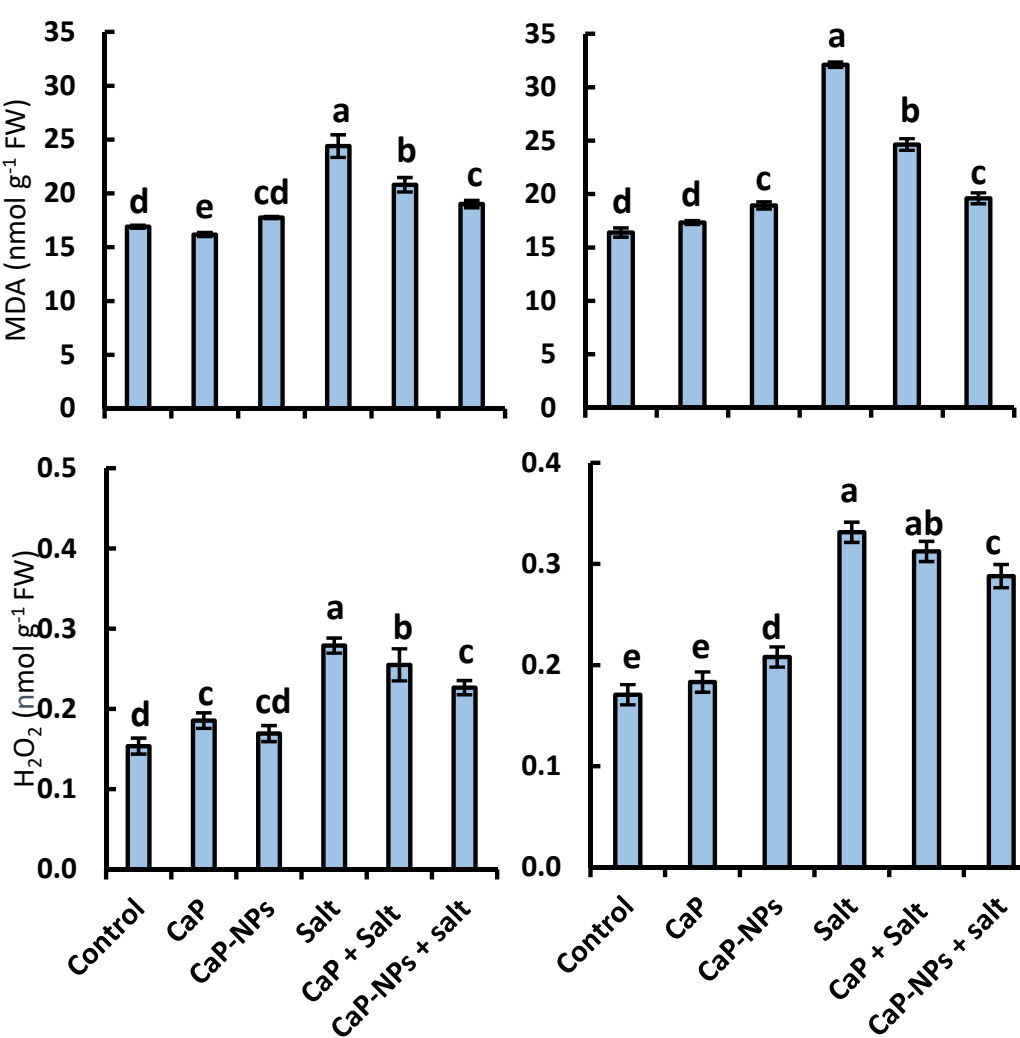

Pod set stage

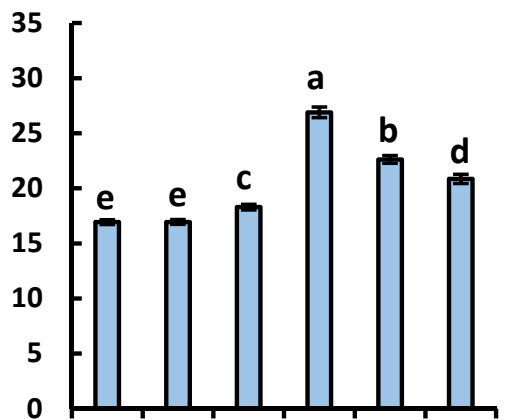

0.5

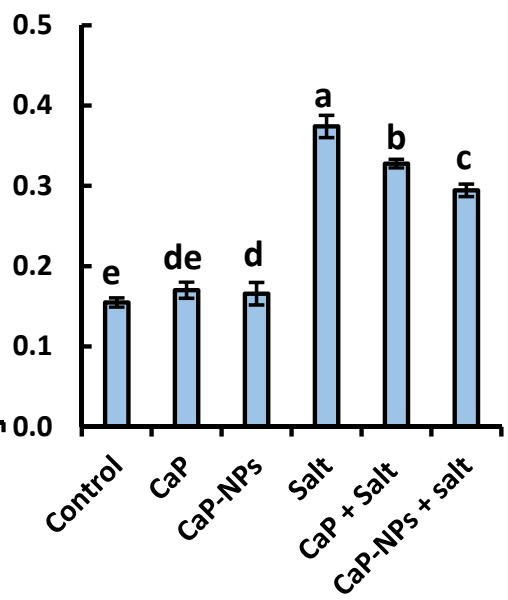

Figure 8. Effect of different treatments on (A) MDA and (B) $\mathrm{H}_{2} \mathrm{O}_{2}$ of broad bean plants in 3 growth stages. The same letters indicate no significant difference $(p<0.05)$ as analyzed by the Duncan test. Each value is the average of 3 replicates \pm SE.

The content of $\mathrm{H}_{2} \mathrm{O}_{2}$ exhibited the same response showed with MDA with two exceptions concerning CaP treatments (Figure 8B). The first, $\mathrm{CaP}$ enhanced $\mathrm{H}_{2} \mathrm{O}_{2}$ content at the vegetative stage, compared with the corresponding control. The second, $\mathrm{CaP}$ failed to ameliorate $\mathrm{H}_{2} \mathrm{O}_{2}$ accumulation associated with salinity stress.

\subsection{Antioxidant Enzymes Activities}

The ordinary fertilizer enhanced POX activity reaching $119 \%$ of corresponding control at the vegetative stage that was neglected at the next developmental stages (Figure 9A). On the other hand, CaP-NPs treatment was accompanied by an $18 \%$ to $29 \%$ increase in POX activity at all developmental stages. Salinity stress enhanced POX activity reaching $181 \%, 208 \%$, and $187 \%$ of corresponding control at vegetative, flowering, and pod set stages, respectively. CaP significantly culminated POX activity stimulated by salt stress treatment at all stages while CaP-NPs failed to mitigate POX response to salinity except at the flowering stage.

Compared with the corresponding control, both fertilizers had a significant stimulatory effect on CAT activity that was more recognizable for CaP-NPs at the flowering stage (Figure 9B). Applying salt stress was accompanied by a $21 \%$ to $178 \%$ increase at all stages. Both fertilizers intensified the salinity effect on CAT activity that was more pronounced for $\mathrm{CaP}-\mathrm{NPs}$ at the flowering stage.

Considering the corresponding control, $\mathrm{CaP}$ enhanced SOD activity at the vegetative stage that faded at the next developmental stages (Figure 9C). Switching to the other fertilizer correlated with $181 \%, 153 \%$, and $131 \%$ of corresponding control at vegetative, flowering, and pod set stages. Salt stress enhanced SOD activity at all stages that were modified by fertilizers. CaP had an alleviatory effect on salinity-provoked SOD activity at 
the first two developmental stages only. On the other side, CaP-NPs mitigated the effect of salt stress on SOD activity at the vegetative stage while enhancing such effect at the last two developmental stages.

(A)
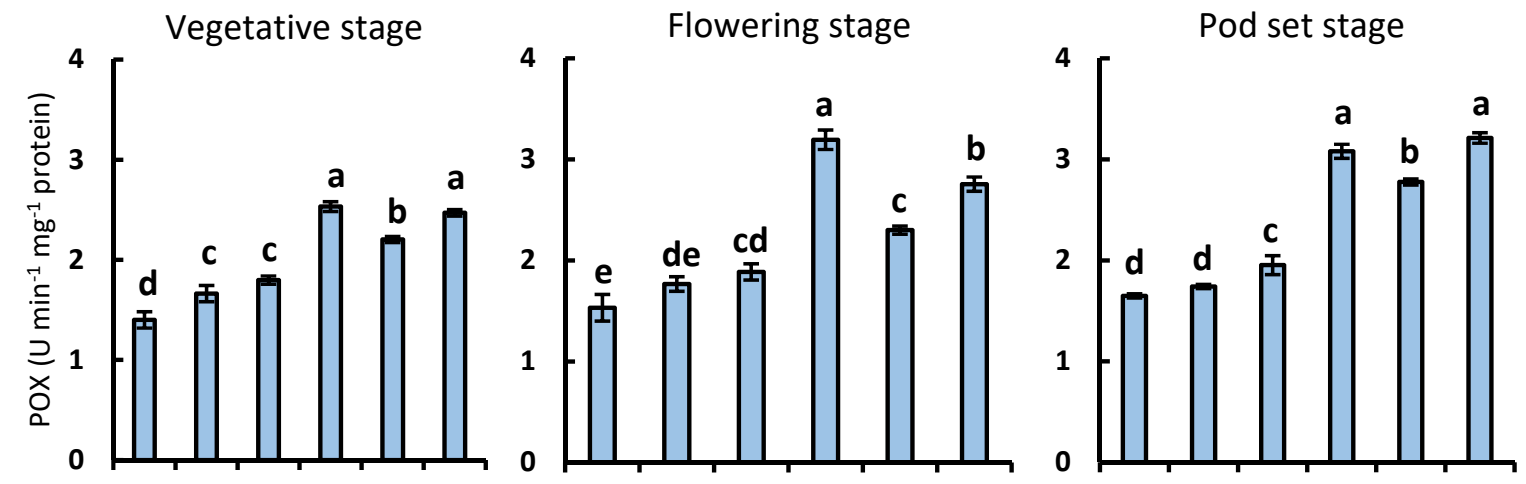

(B)
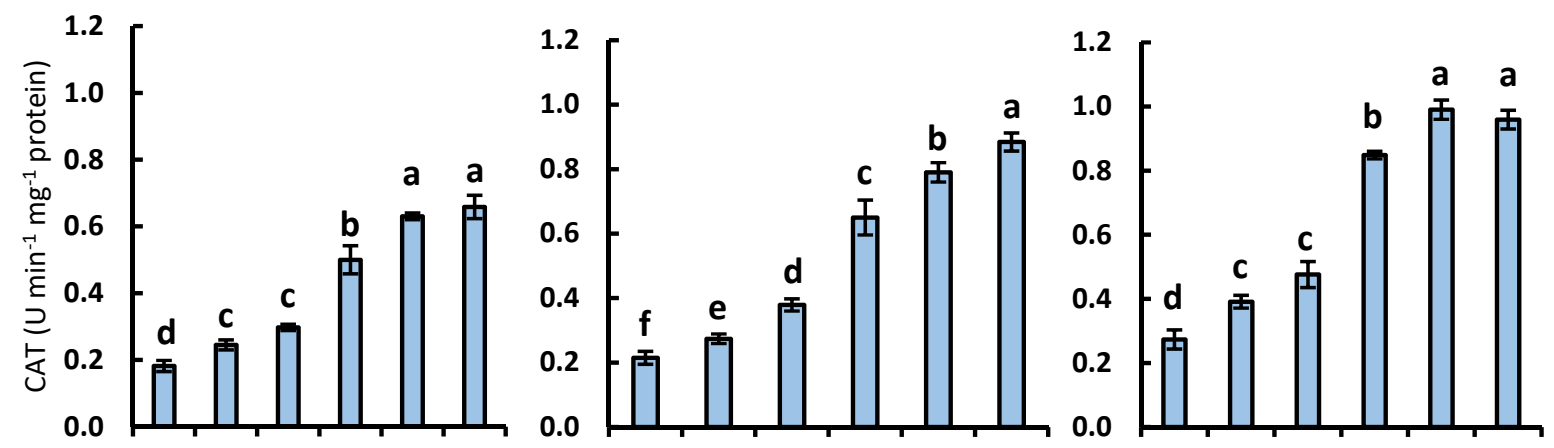

(C)
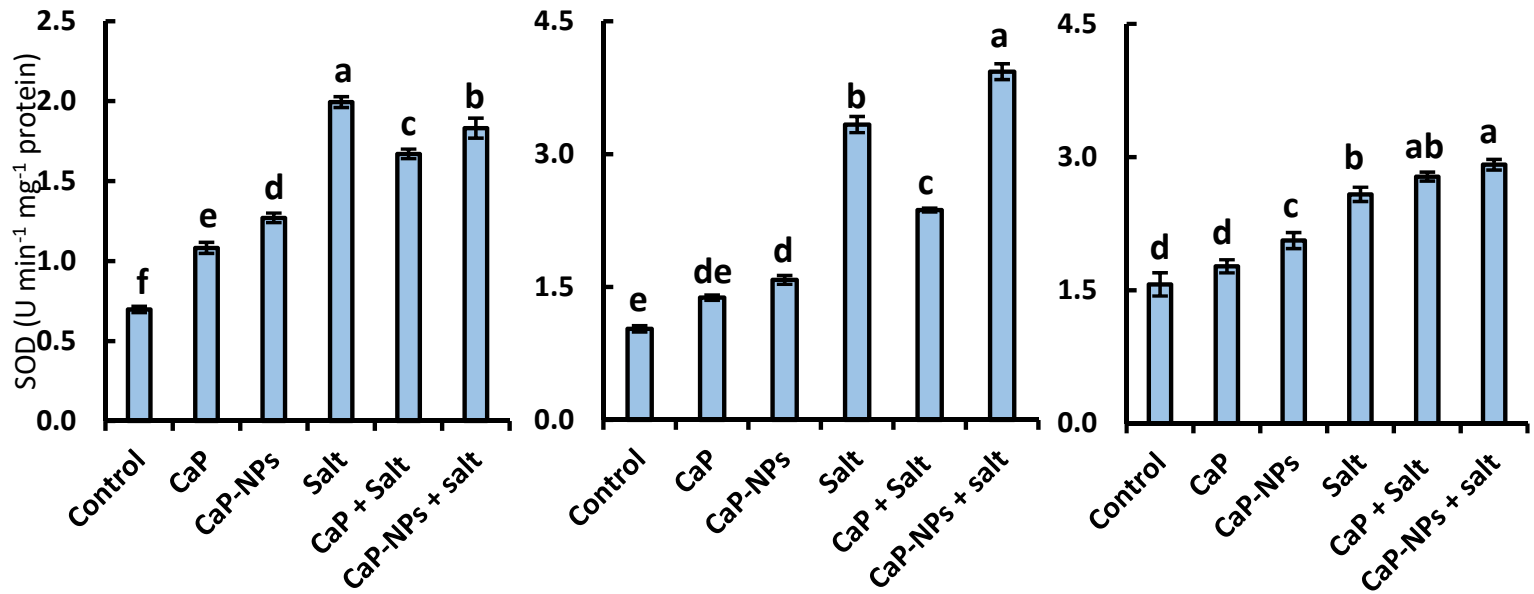

Figure 9. Effect of $\mathrm{NaCl}$ stress on (A) POX, (B) CAT, and (C) SOD of broad bean plants in 3 growth stages. The same letters indicate no significant difference $(p<0.05)$ as analyzed by the Duncan test. Each value is the average of 3 replicates \pm SE.

\subsection{Total Phenolic Content}

The CaP treatment increased the phenolics content by $21 \%$ at the vegetative stage and did not affect it at the following two stages (Figure 10A). On the other hand, the CaP-NPs elevated the content by $28 \%, 30 \%$, and $31 \%$ compared to control at the three successive stages, respectively. Salinity exhibited a significant increase in total phenolic content by $83 \%, 72 \%$, and $78 \%$, respectively, at the sequential stages. CaP significantly ameliorated. The impact of salt stress on phenolics accumulation at all developmental stages was also observed for CaP-NPs but only at the pod set stage. 
(A)

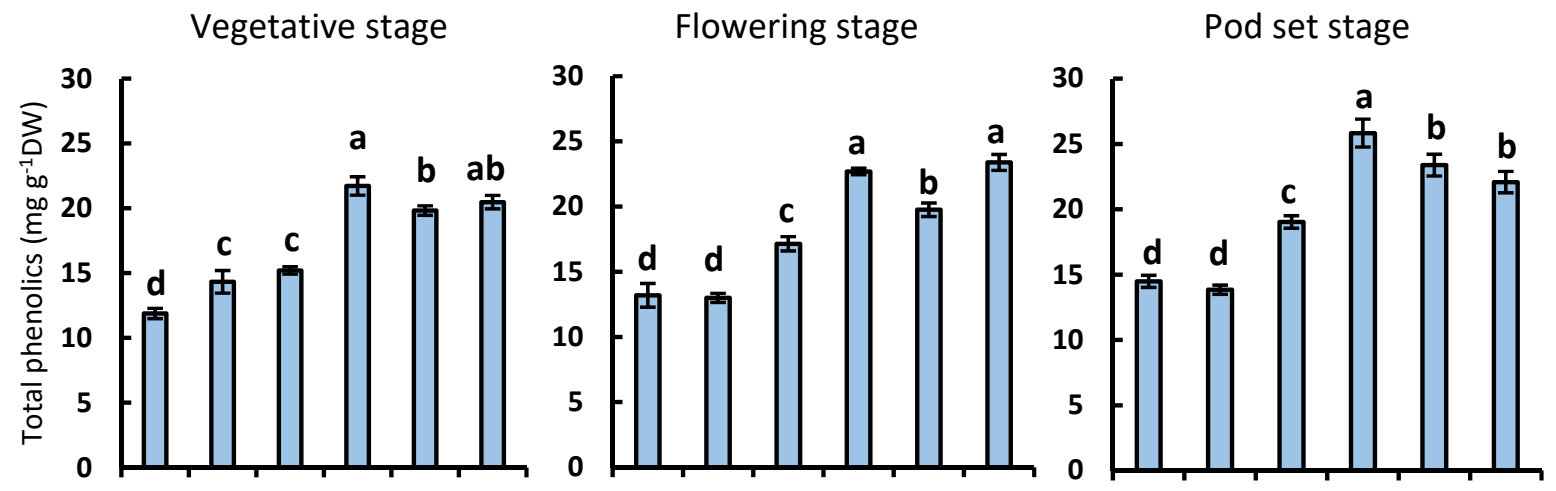

(B)
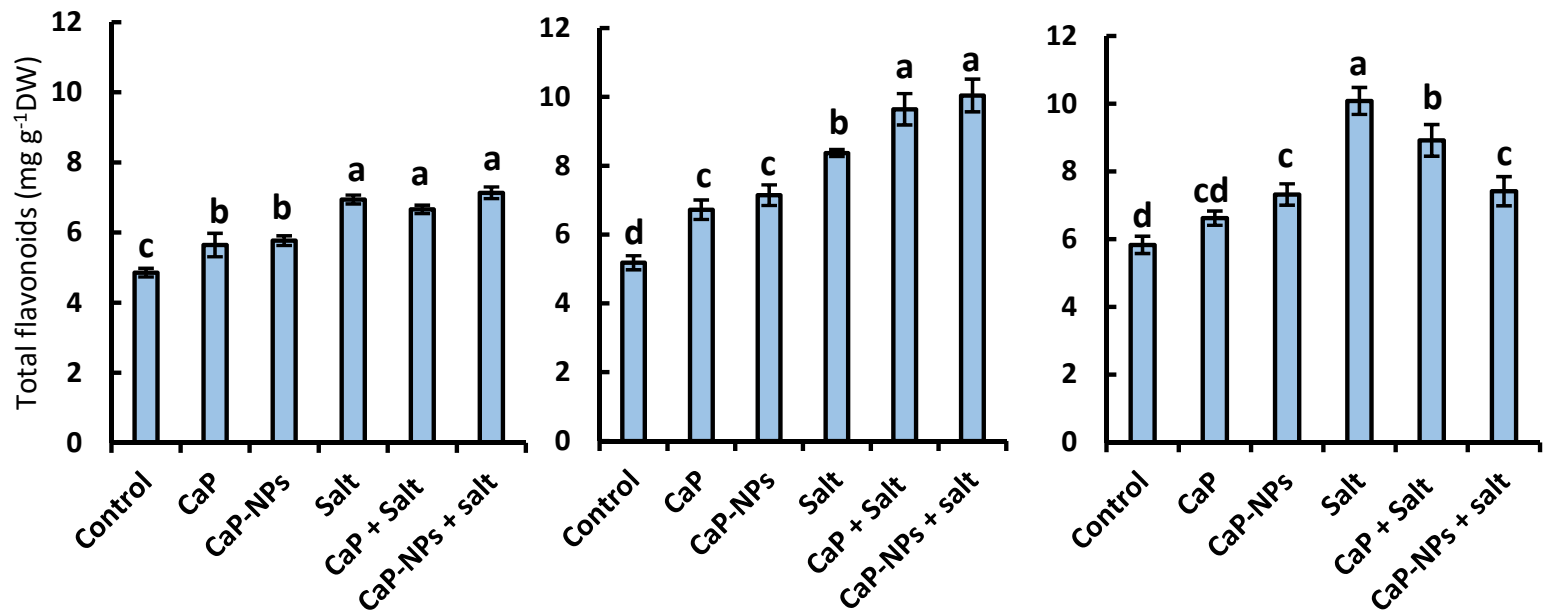

Figure 10. Effect of different treatments on (A) the total phenolics and (B) total flavonoid content of broad bean plants in 3 growth stages. The same letters indicate no significant difference $(p<0.05)$ as analyzed by the Duncan test. Each value is the average of 3 replicates $\pm \mathrm{SE}$.

\subsection{Total Flavonoids Content}

Both fertilizers increased flavonoids content equally at all stages except failure of $\mathrm{CaP}$ at pod set stage (Figure 10B). Compared with the corresponding control, plants accumulated extra total flavonoids under salt conditions by $42 \%, 62 \%$, and $73 \%$ at the vegetative, flowering, and pod set stages, respectively. Both fertilizers failed to modify flavonoids response under salt stress at vegetative stage though equally amplified such response at the middle developmental stage then culminated it at pod set stage.

\section{Discussion}

Results of the present investigation reflected the oxidative stress exemplified by the generation of $\mathrm{H}_{2} \mathrm{O}_{2}$ as a result of experiencing salt treatment. Accumulation of $\mathrm{H}_{2} \mathrm{O}_{2}$ and other ROS explains lipid peroxidation recorded in this study as indicated by an increase in MDA in plants exposed to salinity stress. Increased polyunsaturated fatty acid peroxidation reduces membrane fluidity and increases leakiness, resulting in severe membrane damage [52] responsible for growth retardation and decreased pigment content documented in the current results following salt stress. Ahmad et al. [13] observed an increase in $\mathrm{H}_{2} \mathrm{O}_{2}$ and MDA levels in association with a decrease in the growth and pigments of pea leaves in response to salinity. Similarly, Frukh et al. [53] documented that accumulation of $\mathrm{H}_{2} \mathrm{O}_{2}$ induced more MDA in rice under salt stress.

Reduction in total chlorophyll and carotenoid content in plants under saline stress is a common occurrence that has been observed in a variety of plants [54]. Inhibition of chlorophyll production via activation of chlorophyllase enzymes and membrane degradation are two probable explanations for this decline [55]. The change in chlorophyll pigment has been attributed to oxidative stress, inactivation of the Rubisco enzyme [56] and changes of chloro- 
phyll ultrastructure [57]. In addition to the function as an accessory pigment, carotenoids show antioxidant properties; the increased carotenoids/chlorophyll ratio is an approach to prevent photo-oxidation [58]. Under salt stress, increased carotenoids/chlorophyll was recorded in maize [59], Leptochloa fusca [58] and sugarcane [60].

As a powerful oxidant, $\mathrm{H}_{2} \mathrm{O}_{2}$ causes a variety of harmful consequences in plants when converted to hydroxyl anion. Plants have a multifaceted antioxidant system made of enzymatic and non-enzymatic processes that are engaged in detecting, detoxifying, eliminating, and neutralization of ROS overproduction to maintain cellular redox equilibrium [61].

Antioxidants are considered to be critical in the plant's defense against ROS in this situation. The ascorbate-glutathione cycle is a major hydrogen peroxide detoxification system in plant cells, in which SOD enzymes play a vital role in accelerating the conversion of $\mathrm{H}_{2} \mathrm{O}_{2}$ to $\mathrm{H}_{2} \mathrm{O}$ using ascorbate as a particular electron donor. SOD converts superoxide radicals into $\mathrm{H}_{2} \mathrm{O}_{2}$ and oxygen, $\mathrm{CAT}$ decomposes $\mathrm{H}_{2} \mathrm{O}_{2}$ into water and oxygen molecules [20]. POX is responsible for the elimination of the overproduced $\mathrm{H}_{2} \mathrm{O}_{2}$ by oxidation of various phenolic substrates [21].

The present investigation reflected an increase in SOD, CAT, and POX activities in response to salinity stress. In agreement with these results, Khan et al. [62] recorded a raise in the three enzymes activities under 120 and $150 \mathrm{mM} \mathrm{NaCl}$ in pearl millet. Additionally, Ahmad et al. [23] demonstrated an elevation in SOD and CAT activities in salt-stressed tomato seedlings. Non-enzymatic antioxidant activity exhibited by flavonoids and phenolic compounds deactivate lipid-free radicals. Furthermore, as flavonoids can interact with the polar region of phospholipids, they contribute to membrane lipid homeostasis preventing envelope membrane disruption and oxidative injury by inhibiting lipoxygenase enzyme and preventing polyunsaturated fatty acids conversion to oxygen-containing derivatives [63]. Accumulation of flavonoids is a clear indicator of salt tolerance [64] due to the ability to reduce ROS generation [65].

Results presented in Figure 6 reflected an increase in compatible solutes represented by proline as a part of plant response to salt stress. Proline may operate as a non-toxic osmotic solute, maintaining the structure of macromolecules and organelles preferentially. It has been observed that a high quantity of proline protects plants from osmotic stressors by stabilizing numerous functional units such as complex II electron transport, membranes, proteins, and enzymes as RUBISCO [66]. In harmony with these results, an increase in proline accumulation was documented in wheat [8], pearl millet [62] and Pisum sativum [13]. Our study revealed the accumulation of soluble sugars by salt treatment at the vegetative stage. This enhancement helps the plant to adjust the osmotic balance, scavenge ROS, and provide energy to resist salinity $[13,67,68]$. Meanwhile, a significant decrease in soluble sugar content was detected at flowering and pod set stages that were significantly positively correlated with the reduction in chlorophyll pigment under salt stress (Table S1).

Qados et al. [69], Hassanein et al. [70], and Taie et al. [71] documented that soluble carbohydrates decreased with an increase of $\mathrm{NaCl}$ in soil. Similar to the results of the present investigation, Qados et al. [69] proved that the application of Si NPs alleviated salt stress by decreasing soluble sugar synthesis. $\mathrm{NaCl}$ stress limits photosynthesis, causing plants to shift carbohydrate synthesis to secondary metabolites. As shown in Table S1, soluble sugars are significantly negatively correlated with total phenolics and flavonoids.

Results recorded for growth parameters and pigments content reflected the ameliorating effect of the applied fertilizers against salt stress that was undoubted for CaP-NPs. It has been reported that $\mathrm{Ca}^{2+}$ and $\mathrm{P}$ supplements stimulated several defense mechanisms to reduce $\mathrm{NaCl}$ toxicity. Both $\mathrm{Ca}^{2+}$ and $\mathrm{P}$ fertilizers play a key role in $\mathrm{K}^{+}$homeostasis in plant cells. $\mathrm{P}$ stimulates the accumulation of $\mathrm{Na}^{+}$in the vacuole and, therefore, the concentration of $\mathrm{K}^{+}$increases in the cytosol [72]. The following is an explanation of how the administration of $\mathrm{P}$ stimulates the buildup of $\mathrm{Na}^{+}$in the vacuole: $\mathrm{Both} \mathrm{H}^{+}$adenosine triphosphatase and pyrophosphatase pumps acidify the inside of the vacuole with $\mathrm{H}^{+}$, prompting the $\mathrm{H}^{+} / \mathrm{Na}^{+}$antiport protein to substitute the cytosol's $\mathrm{Na}^{+}$with the vacuole's $\mathrm{H}^{+}$[73]. Similar to our results, Roy et al. [24], Ahmad et al. [23], de Andrade et al. [25], and 
Mohamed et al. [26] reported that $\mathrm{P}$ or $\mathrm{Ca}^{2+}$ supplements improved the crops' resistance to soil salinity.

Furthermore, a sufficient supply of $\mathrm{Ca}^{2+}$ controls the ion homeostasis pathways in plants by limiting the entry of $\mathrm{Na}^{+}$. In addition, calcium plays a role in the regulation of phospholipid signaling in response to osmotic stress [74]. $\mathrm{Ca}^{2+}$-phospholipid signaling system communication regulates phospholipids, inositol, fatty acids, and ROS. It also maintains cellular osmotic equilibrium [75]. On the other hand, $\mathrm{P}$ is a critical component of biological substances such as nucleic acids, nucleotides, phospholipids, and phosphoproteins making it the most important plant growth macronutrient [76,77]. In addition, it is involved in various metabolic activities, including energy transfer, signal transduction, macromolecular biosynthesis, photosynthesis, and respiration [78]. Phosphate molecules serve as the "carbon currency" within plants [79].

Comparing the behavior of the recorded parameters in response to different treatments suggests amplification of catalase activity and the resultant decrease in $\mathrm{H}_{2} \mathrm{O}_{2}$ content accompanied with a decrease in lipid peroxidation as a potential mechanism underlying the observed role of fertilizers against salinity that was more pronounced for nano-type. Supporting this point of view, Upadhyaya et al. [80] reported that CaP-NPs decreased MDA and ROS at 10 and $20 \mathrm{mg} \mathrm{L}^{-1}$ by elevating antioxidant enzymes such as CAT. Additionally, $\mathrm{Xu}$ et al. [66] observed a significant increase in SOD, CAT, and POX and a simultaneous decrease in ROS production in Calligonum mongolicum plants supplemented with $\mathrm{Ca}^{2+}$ under oxidative stress. The ability of $\mathrm{Ca}^{2+}$ to enhance SOD and CAT was also confirmed in tomato [23] and rice [81].

Results of the current study also reflected the priority of nano form over ionic one in the stimulation of SOD. Similarly, SOD activity is enhanced by the application of other NPs including Mn NPs on pepper [82], nano-silicon on alfalfa [69], Ag NPs on pearl millet [62] under salt stress.

Results recorded for compatible solutes suggest a potential role for fertilizers to create an osmoregulatory mechanism independent of proline under salinity stress conditions. Such a mechanism allowed allocation of more assimilated carbon to its normal sinks reflected in more or less normal growth and yield upon application of CaP-NPs to saltstressed plants. As indicated in the present study, the application of $\mathrm{CaP}$ and CaP-NPs alleviated the inhibitory effect of salt stress by stimulation of new sugars synthesis. In this context, Qados et al. [69] reported that nano-silicon increased sugar in broad bean and El-Sharkawy et al. [83] also reported these osmo-protectants in alfalfa by application nano $\mathrm{K}$ under salt stress. Mohamed et al. [17] also demonstrated the Ag NPs-mediated increase in soluble sugars content of wheat leaves under salt stress. One of the salt-mitigatory mechanisms of some fertilizers is an increasing in soluble sugars content which is reported in $\mathrm{P}$ application on potato [25], potassium fertilizer on soybean [84] and $\mathrm{Ca}^{2+}$ supplementation on Calligonum mongolicum [66].

It has been reported that the application of some fertilizers ameliorated abiotic stresses by increasing soluble sugars synthesis to maintain osmotic balance independent on proline, as using silicon to limit salt toxicity on Glycyrrhiza uralensis [85], and tobacco [86]. Additionally, it occurred by applying combined fertilizer (NPK, PGPR, and vermicompost) on Brassica napus under drought stress [87].

However, the reduction in proline has been observed in several studies as in Wang et al. [88] and Rossi et al. [89], who documented that proline did not participate in salt tolerance using $\mathrm{CeO}_{2} \mathrm{NPs}$ and plant improve other defense mechanisms as photosynthesis and antioxidant system. Avestan et al. [90], recorded salt tolerance mechanisms in strawberry using $\mathrm{SiO}_{2} \mathrm{NPs}$ through improving growth, chlorophyll content, relative water content, and limiting proline accumulation. In the case of salt-stressed grape plants, using Fe NPs and potassium silicate together mitigated salt injury by lowering MDA, proline, and increasing total proteins, SOD, APX, and POX activities [91].

The present investigation has shown that sugars play a more important role in osmotic adjustment than proline in CaP-NPs treatment under salt stress. Similarly, Yang et al. [92] 
reported that using calcium silicate slag lowered proline and accumulated soluble sugars in rice leaves under drought stress. The authors explained the opposite correlation between proline and sugar to the competition for carbon skeletons. In addition, P fertilizers reduced proline under salinity stress in Cicer arietinum [93], and drought stress in dwarf bamboo [94].

The negative correlation recorded between proline and chlorophyll (Table S1) provides another possible explanation for proline reduction where glutamate is a common precursor in proline and chlorophyll synthesis [95]. The applied fertilizer reduced proline to improve the synthesis of green pigments in leaves as reported by Mamnabi et al. [87]. The current results showed the better performance of CaP-NPs against salt stress compared with $\mathrm{CaP}$ as $\mathrm{CaP}-\mathrm{NPs}$ accumulated higher total soluble sugars, especially in the flowering and pod set stages to mitigate the osmotic stress. Additionally, it induced CAT and POX activities as antioxidant ROS scavengers resulted in less MDA and less $\mathrm{H}_{2} \mathrm{O}_{2}$ content.

It could be added that $\mathrm{CaP}-\mathrm{NPs}$ provide $\mathrm{Ca}^{2+}$ and $\mathrm{P}$ to plants on a nanoscale, which may reduce ion toxicity caused by salt stress. $\mathrm{P}$ nutrients in a nano-formulation are more effective than traditional fertilizer [96]. In case of changes in $\mathrm{pH}$ or presence of some cations in soil, the P NPs may remain relatively stable at the suspension and less damaged by solution $\mathrm{pH}$, coexisting ions, or solids, while soluble phosphate will be removed more quickly from a solution phase through precipitation. In phosphorus NPs, there was substantially more P left in the growth media for plant roots to absorb.

\section{Conclusions}

Salinity adversely affects the growth and yield in broad bean plants due to the induction of osmotic stress, ionic toxicity, and excessive generation of toxic ROS that negatively influence cell functional integrity, and cause oxidation of cell molecules such as proteins, lipids, and chlorophyll. Our results demonstrated that the applied fertilizers (CaP and CaP-NPs) generally mitigated these injures by enhancing the defense mechanisms, especially antioxidant enzymes and accumulation of soluble sugars. Furthermore, nano-fertilizer was the first runner being more resistant to alterations in soil conditions. Therefore, this study put a solid base for further open-field studies aiming to evaluate the future of replacing the conventional fertilizers containing $\mathrm{Ca}^{2+}$ or $\mathrm{P}$ with their nano form to alleviate the harmful effect of salinity stress and to improve the productivity of broad beans. In addition, our study would be beneficial for other studies involved in the application of nano-fertilizer in agriculture.

Supplementary Materials: The following supporting information can be downloaded at: https:/ / www.mdpi.com/article/10.3390/horticulturae8010075/s1, Table S1: The correlation matrix heatmap shows the values of the Pearson correlation coefficient for all studied parameters.

Author Contributions: Conceptualization, M.A.M.A., A.S.F. and M.A.K.; methodology, A.K.N.; software, A.K.N. and A.A.K.; validation, A.K.N.; formal analysis, M.A.M.A., A.A.K. and M.M.E.-M.; investigation, A.K.N., M.A.M.A., A.A.K. and M.M.E.-M.; resources, M.A.M.A. and M.A.K.; data curation, A.K.N.; writing the original draft preparation, A.K.N., M.A.M.A., A.A.K. and M.M.E.-M.; writing, review and editing, M.A.K., A.S.F., M.M.E.-M., A.A.K. and M.A.M.A.; visualization, A.K.N., M.A.M.A., A.A.K. and M.M.E.-M.; supervision, M.A.K., A.S.F. and M.A.M.A.; project administration, M.A.M.A. All authors have read and agreed to the published version of the manuscript.

Funding: This research received no external funding.

Institutional Review Board Statement: Not applicable.

Informed Consent Statement: Not applicable.

Acknowledgments: The authors would like to sincerely thank the administration of the Agricultural Genetic Engineering Research Institute (AGERI), as well as the administration of the Agricultural Research Center (ARC), Egypt, for their continued support.

Conflicts of Interest: The authors declare no conflict of interest. 


\section{References}

1. Singh, A.K.; Bharati, R.; Pedpati, A. An assessment of faba bean (Vicia faba L.) current status and future prospect. Afr. J. Agric. Res. 2013, 8, 6634-6641. [CrossRef]

2. Kumar, A.; Prasad, N.; Sinha, S.K. Nutritional and antinutritional attributes of faba bean (Vicia faba L.) germplasms growing in Bihar, India. Physiol. Mol. Biol. Plants 2015, 21, 159-162. [CrossRef]

3. Barton, L.; Thamo, T.; Engelbrecht, D.; Biswas, W.K. Does growing grain legumes or applying lime cost effectively lower greenhouse gas emissions from wheat production in a semi-arid climate? J. Clean. Prod. 2014, 83, 194-203. [CrossRef]

4. El-Mogy, M.M.; Garchery, C.; Stevens, R. Irrigation with salt water affects growth, yield, fruit quality, storability and marker-gene expression in cherry tomato. Acta Agric. Scand. Sect. B Soil Plant Sci. 2018, 68, 727-737. [CrossRef]

5. Machado, R.M.A.; Serralheiro, R.P. Soil salinity: Effect on vegetable crop growth. Management practices to prevent and mitigate soil salinization. Horticulturae 2017, 3, 30. [CrossRef]

6. Lhissoui, R.; El Harti, A.; Chokmani, K. Mapping soil salinity in irrigated land using optical remote sensing data. Eurasian J. Soil Sci. 2014, 3, 82-88. [CrossRef]

7. Scudiero, E.; Skaggs, T.H.; Corwin, D.L. Comparative regional-scale soil salinity assessment with near-ground apparent electrical conductivity and remote sensing canopy reflectance. Ecol. Indic. 2016, 70, 276-284. [CrossRef]

8. Alzahrani, O.; Abouseadaa, H.; Abdelmoneim, T.K.; Alshehri, M.A.; Mohamed, E.-M.; El-Beltagi, H.S.; Atia, M.A.M. Agronomical, physiological and molecular evaluation reveals superior salt-tolerance in bread wheat through salt-induced priming approach. Not. Bot. Horti Agrobot. Cluj-Napoca 2021, 49, 12310. [CrossRef]

9. Abdeldym, E.A.; El-Mogy, M.M.; Abdellateaf, H.R.; Atia, M.A. Genetic Characterization, Agro-Morphological and Physiological Evaluation of Grafted Tomato under Salinity Stress Conditions. Agronomy 2020, 10, 1948. [CrossRef]

10. Abdelgawad, K.F.; El-Mogy, M.M.; Mohamed, M.I.A.; Garchery, C.; Stevens, R.G. Increasing Ascorbic Acid Content and Salinity Tolerance of Cherry Tomato Plants by Suppressed Expression of the Ascorbate Oxidase Gene. Agronomy 2019, 9, 51. [CrossRef]

11. Almeida, D.M.; Oliveira, M.M.; Saibo, N.J. Regulation of $\mathrm{Na}^{+}$and $\mathrm{K}^{+}$homeostasis in plants: Towards improved salt stress tolerance in crop plants. Genet. Mol. Biol. 2017, 40, 326-345. [CrossRef] [PubMed]

12. Khan, N.; Bano, A.; Babar, M.A. The stimulatory effects of plant growth promoting rhizobacteria and plant growth regulators on wheat physiology grown in sandy soil. Arch. Microbiol. 2019, 201, 769-785. [CrossRef]

13. Ahmad, F.; Kamal, A.; Singh, A.; Ashfaque, F.; Alamri, S.; Siddiqui, M.H. Salicylic acid modulates antioxidant system, defense metabolites, and expression of salt transporter genes in Pisum sativum under salinity stress. J. Plant Growth Regul. 2020, 1-14. [CrossRef]

14. Julkowska, M.M.; Testerink, C. Tuning plant signaling and growth to survive salt. Trends Plant Sci. 2015, 20, 586-594. [CrossRef]

15. Annunziata, M.G.; Ciarmiello, L.F.; Woodrow, P.; Maximova, E.; Fuggi, A.; Carillo, P. Durum wheat roots adapt to salinity remodeling the cellular content of nitrogen metabolites and sucrose. Front. Plant Sci. 2017, 7, 2035. [CrossRef]

16. Reddy, I.N.B.L.; Kim, S.-M.; Kim, B.-K.; Yoon, I.-S.; Kwon, T.-R. Identification of rice accessions associated with $\mathrm{K}^{+} / \mathrm{Na}^{+}$ratio and salt tolerance based on physiological and molecular responses. Rice Sci. 2017, 24, 360-364. [CrossRef]

17. Mohamed, A.K.S.; Qayyum, M.F.; Abdel-Hadi, A.M.; Rehman, R.A.; Ali, S.; Rizwan, M. Interactive effect of salinity and silver nanoparticles on photosynthetic and biochemical parameters of wheat. Arch. Agron. Soil Sci. 2017, 63, 1736-1747. [CrossRef]

18. Gratão, P.L.; Polle, A.; Lea, P.J.; Azevedo, R.A. Making the life of heavy metal-stressed plants a little easier. Funct. Plant Biol. 2005, 32, 481-494. [CrossRef] [PubMed]

19. Abouzari, A.; Fakheri, B.A. Reactive oxygen species: Generation, oxidative damage, and signal transduction. Int. J. Life Sci. 2015, 9, 3-17. [CrossRef]

20. Waszczak, C.; Carmody, M.; Kangasjärvi, J. Reactive oxygen species in plant signaling. Annu. Rev. Plant Biol. 2018, 69, 209-236. [CrossRef] [PubMed]

21. Bela, K.; Horváth, E.; Gallé, Á.; Szabados, L.; Tari, I.; Csiszár, J. Plant glutathione peroxidases: Emerging role of the antioxidant enzymes in plant development and stress responses. J. Plant Physiol. 2015, 176, 192-201. [CrossRef] [PubMed]

22. Selmar, D.; Kleinwächter, M. Stress enhances the synthesis of secondary plant products: The impact of stress-related over-reduction on the accumulation of natural products. Plant Cell Physiol. 2013, 54, 817-826. [CrossRef]

23. Ahmad, P.; Abd_Allah, E.F.; Alyemeni, M.N.; Wijaya, L.; Alam, P.; Bhardwaj, R.; Siddique, K.H. Exogenous application of calcium to 24-epibrassinosteroid pre-treated tomato seedlings mitigates $\mathrm{NaCl}$ toxicity by modifying ascorbate-glutathione cycle and secondary metabolites. Sci. Rep. 2018, 8, 13515. [CrossRef]

24. Roy, P.R.; Tahjib-Ul-Arif, M.; Polash, M.A.S.; Hossen, M.Z.; Hossain, M.A. Physiological mechanisms of exogenous calcium on alleviating salinity-induced stress in rice (Oryza sativa L.). Physiol. Mol. Biol. Plants 2019, 25, 611-624. [CrossRef]

25. De Andrade, F.H.A.; Pereira, W.E.; Maia, J.M.; Clemente, M.I.B.; de Sousa Lima, J.; Silva, V.A. Phosphorus Increases K ${ }^{+}$in the Shoot and Improves Salinity Tolerance in Sweetsop Seedlings. J. Plant Growth Regul. 2021, 1-12. [CrossRef]

26. Mohamed, H.I.; El-Sayed, A.A.; Rady, M.M.; Caruso, G.; Sekara, A.; Abdelhamid, M.T. Coupling effects of phosphorus fertilization source and rate on growth and ion accumulation of common bean under salinity stress. PeerJ 2021, 9, e11463. [CrossRef]

27. Sattari, S.Z.; Bouwman, A.F.; Giller, K.E.; van Ittersum, M.K. Residual soil phosphorus as the missing piece in the global phosphorus crisis puzzle. Proc. Natl. Acad. Sci. USA 2012, 109, 6348-6353. [CrossRef]

28. Carpenter, S.R. Phosphorus control is critical to mitigating eutrophication. Proc. Natl. Acad. Sci. USA 2008, 105, 11039-11040. [CrossRef] 
29. Maghsoodi, M.R.; Ghodszad, L.; Lajayer, B.A. Dilemma of hydroxyapatite nanoparticles as phosphorus fertilizer: Potentials, challenges and effects on plants. Environ. Technol. Innov. 2020, 19, 100869. [CrossRef]

30. Rajput, V.D.; Minkina, T.; Kumari, A.; Singh, V.K.; Verma, K.K.; Mandzhieva, S.; Sushkova, S.; Srivastava, S.; Keswani, C. Coping with the Challenges of Abiotic Stress in Plants: New Dimensions in the Field Application of Nanoparticles. Plants 2021, 10, 1221. [CrossRef]

31. Almutairi, Z.M. Effect of nano-silicon application on the expression of salt tolerance genes in germinating tomato (Solanum lycopersicum L.) seedlings under salt stress. Plant Omics 2016, 9, 106-114.

32. Rossi, L.; Zhang, W.; Ma, X. Cerium oxide nanoparticles alter the salt stress tolerance of Brassica napus L. by modifying the formation of root apoplastic barriers. Environ. Pollut. 2017, 229, 132-138. [CrossRef] [PubMed]

33. Aziz, Y.; Shah, G.A.; Rashid, M.I. ZnO nanoparticles and zeolite influence soil nutrient availability but do not affect herbage nitrogen uptake from biogas slurry. Chemosphere 2019, 216, 564-575. [CrossRef]

34. Sun, D.; Hussain, H.I.; Yi, Z.; Rookes, J.E.; Kong, L.; Cahill, D.M. Mesoporous silica nanoparticles enhance seedling growth and photosynthesis in wheat and lupin. Chemosphere 2016, 152, 81-91. [CrossRef]

35. Ghafariyan, M.H.; Malakouti, M.J.; Dadpour, M.R.; Stroeve, P.; Mahmoudi, M. Effects of magnetite nanoparticles on soybean chlorophyll. Environ. Sci. Technol. 2013, 47, 10645-10652. [CrossRef]

36. Rane, M.; Bawskar, M.; Rathod, D.; Nagaonkar, D.; Rai, M. Influence of calcium phosphate nanoparticles, Piriformospora indica and Glomus mosseae on growth of Zea mays. Adv. Nat. Sci. Nanosci. Nanotechnol. 2015, 6, 045014. [CrossRef]

37. Merwad, A.-R.M.; Desoky, E.-S.M.; Rady, M.M. Response of water deficit-stressed Vigna unguiculata performances to silicon, proline or methionine foliar application. Sci. Hortic. 2018, 228, 132-144. [CrossRef]

38. Sestak, Z.; Catsky, J.; Jarvis, P. Determination of chlorophylls a and b. In Plant Photosynthetic Production; Springer: Amsterdam, The Netherlands, 1971; pp. 672-701.

39. Maness, N. Extraction and analysis of soluble carbohydrates. In Plant Stress Tolerance; Springer: Amsterdam, The Netherlands, 2010; pp. 341-370. [CrossRef]

40. Yemm, E.; Willis, A. The estimation of carbohydrates in plant extracts by anthrone. Biochem. J. 1954, 57, 508-514. [CrossRef]

41. Shabnam, N.; Tripathi, I.; Sharmila, P.; Pardha-Saradhi, P. A rapid, ideal, and eco-friendlier protocol for quantifying proline. Protoplasma 2016, 253, 1577-1582. [CrossRef]

42. Grace, S.C.; Logan, B.A. Acclimation of foliar antioxidant systems to growth irradiance in three broad-leaved evergreen species Plant Physiol. 1996, 112, 1631-1640. [CrossRef]

43. Lagrimini, L. Plant peroxidases: Under-and over-expression in transgenic plants and physiological consequences. Plant Peroxidases 1980, 1990, 59-69. [CrossRef]

44. Aebi, H. Catalase in vitro. Methods Enzymol. 1984, 105, 121-126. [CrossRef]

45. Dhindsa, R.S.; Plumb-Dhindsa, P.; Thorpe, T.A. Leaf senescence: Correlated with increased levels of membrane permeability and lipid peroxidation, and decreased levels of superoxide dismutase and catalase. J. Exp. Bot. 1981, 32, 93-101. [CrossRef]

46. Lowry, O.H.; Rosebrough, N.J.; Farr, A.L.; Randall, R.J. Protein measurement with the Folin phenol reagent. J. Biol. Chem. 1951, 193, 265-275. [CrossRef]

47. Heath, R.L.; Packer, L. Photoperoxidation in isolated chloroplasts: I. Kinetics and stoichiometry of fatty acid peroxidation. Arch Biochem. Biophys. 1968, 125, 189-198. [CrossRef]

48. Junglee, S.; Urban, L.; Sallanon, H.; Lopez-Lauri, F. Optimized assay for hydrogen peroxide determination in plant tissue using potassium iodide. Am. J. Anal. Chem. 2014, 5, 730. [CrossRef]

49. Sauvesty, A.; Page, F.; Huot, J. A simple method for extracting plant phenolic compounds. Can. J. For. Res. 1992, 22, 654-659. [CrossRef]

50. Lowe, L. Total and labile polysaccharide analysis of soils. In Soil Sampling and Methods of Analysis; Lewis Publishers: Boca Raton, FL, USA, 1993; pp. 373-376.

51. Chang, C.-C.; Yang, M.-H.; Wen, H.-M.; Chern, J.-C. Estimation of total flavonoid content in propolis by two complementary colorimetric methods. J. Food Drug Anal. 2002, 10, 3. [CrossRef]

52. Gill, S.S.; Tuteja, N. Reactive oxygen species and antioxidant machinery in abiotic stress tolerance in crop plants. Plant Physiol. Biochem. 2010, 48, 909-930. [CrossRef]

53. Frukh, A.; Siddiqi, T.O.; Khan, M.I.R.; Ahmad, A. Modulation in growth, biochemical attributes and proteome profile of rice cultivars under salt stress. Plant Physiol. Biochem. 2020, 146, 55-70. [CrossRef]

54. Taffouo, V.; Wamba, O.; Youmbi, E.; Nono, G.; Akoa, A. Growth, yield, water status and ionic distribution response of three bambara groundnut (Vigna subterranea (L.) Verdc.) landraces grown under saline conditions. Int. J. Bot. 2010, 6, 53-58. [CrossRef]

55. Parida, A.K.; Das, A.B. Salt tolerance and salinity effects on plants: A review. Ecotoxicol. Environ. Saf. 2005, 60, 324-349. [CrossRef]

56. Soussi, M.; Ocana, A.; Lluch, C. Effects of salt stress on growth, photosynthesis and nitrogen fixation in chickpea (Cicer arietinum L.). J. Exp. Bot. 1998, 49, 1329-1337. [CrossRef]

57. Rady, M.M. Effect of 24-epibrassinolide on growth, yield, antioxidant system and cadmium content of bean (Phaseolus vulgaris L.) plants under salinity and cadmium stress. Sci. Hortic. 2011, 129, 232-237. [CrossRef]

58. Mohammadi, F.; Kavousi, H.R.; Mansouri, M. Effects of salt stress on physio-biochemical characters and gene expressions in halophyte grass Leptochloa fusca (L.) Kunth. Acta Physiol. Plant. 2019, 41, 143. [CrossRef] 
59. Stefanov, M.A.; Rashkov, G.D.; Yotsova, E.K.; Borisova, P.B.; Dobrikova, A.G.; Apostolova, E.L. Different Sensitivity Levels of the Photosynthetic Apparatus in Zea mays L. and Sorghum bicolor L. under Salt Stress. Plants 2021, 10, 1469. [CrossRef]

60. Wahid, A.; Ghazanfar, A. Possible involvement of some secondary metabolites in salt tolerance of sugarcane. J. Plant Physiol. 2006, 163, 723-730. [CrossRef]

61. Liebthal, M.; Maynard, D.; Dietz, K.-J. Peroxiredoxins and redox signaling in plants. Antioxid. Redox Signal. 2018, 28, 609-624. [CrossRef]

62. Khan, I.; Raza, M.A.; Awan, S.A.; Shah, G.A.; Rizwan, M.; Ali, B.; Tariq, R.; Hassan, M.J.; Alyemeni, M.N.; Brestic, M. Amelioration of salt induced toxicity in pearl millet by seed priming with silver nanoparticles (AgNPs): The oxidative damage, antioxidant enzymes and ions uptake are major determinants of salt tolerant capacity. Plant Physiol. Biochem. 2020, 156, 221-232. [CrossRef]

63. Erlejman, A.; Verstraeten, S.; Fraga, C.; Oteiza, P. The interaction of flavonoids with membranes: Potential determinant of flavonoid antioxidant effects. Free Radic. Res. 2004, 38, 1311-1320. [CrossRef]

64. Xu, N.; Liu, S.; Lu, Z.; Pang, S.; Wang, L.; Wang, L.; Li, W. Gene expression profiles and flavonoid accumulation during salt stress in Ginkgo biloba seedlings. Plants 2020, 9, 1162. [CrossRef] [PubMed]

65. Liu, M.; Xu, Y.; Han, X.; Liang, C.; Yin, L.; Xu, L.; Qi, Y.; Zhao, Y.; Peng, J.; Sun, C. Potent effects of flavonoid-rich extract from Rosa laevigata Michx fruit against hydrogen peroxide-induced damage in PC12 cells via attenuation of oxidative stress, inflammation and apoptosis. Molecules 2014, 19, 11816-11832. [CrossRef] [PubMed]

66. Xu, D.; Wang, W.; Gao, T.; Fang, X.; Gao, X.; Li, J.; Bu, H.; Mu, J. Calcium alleviates decreases in photosynthesis under salt stress by enhancing antioxidant metabolism and adjusting solute accumulation in Calligonum mongolicum. Conserv. Physiol. 2017, 5, cox060. [CrossRef]

67. Sagervanshi, A.; Naeem, A.; Geilfus, C.M.; Kaiser, H.; Mühling, K.H. One-time abscisic acid priming induces long-term salinity resistance in Vicia faba: Changes in key transcripts, metabolites, and ionic relations. Physiol. Plant. 2021, 172, 146-161. [CrossRef]

68. Abid, G.; Saidi, M.N.; Ouertani, R.N.; Muhovski, Y.; Jebara, S.H.; Ghouili, E.; Sassi, K.; Baudoin, J.-P.; El Ayed, M.; Elkahoui, S. Differential gene expression reveals candidate genes for osmotic stress response in faba bean (Vicia faba L.) involved in different molecular pathways. Acta Physiol. Plant. 2021, 43, 40. [CrossRef]

69. Qados, A.M.A. Mechanism of nanosilicon-mediated alleviation of salinity stress in faba bean (Vicia faba L.) plants. J. Exp. Agric. Int. 2015, 78-95. [CrossRef]

70. Hassanein, R.; Hashem, H.; Khalil, R. Stigmasterol treatment increases salt stress tolerance of faba bean plants by enhancing antioxidant systems. Plant Omics 2012, 5, 476-485.

71. Taie, H.; Abdelhamid, M.; Dawood, M.; Nassar, R. Pre-sowing seed treatment with proline improves some physiological, biochemical and anatomical attributes of faba bean plants under sea water stress. J. Appl. Sci. Res. 2013, 9, $2853-2867$.

72. Shabala, S.; Pottosin, I. Regulation of potassium transport in plants under hostile conditions: Implications for abiotic and biotic stress tolerance. Physiol. Plant. 2014, 151, 257-279. [CrossRef]

73. Theerawitaya, C.; Tisarum, R.; Samphumphuang, T.; Takabe, T.; Cha-Um, S. Expression levels of the Na ${ }^{+} / \mathrm{K}^{+}$transporter OsHKT2; 1 and vacuolar $\mathrm{Na}+/ \mathrm{H}+$ exchanger OsNHX1, Na enrichment, maintaining the photosynthetic abilities and growth performances of indica rice seedlings under salt stress. Physiol. Mol. Biol. Plants 2020, 26, 513-523. [CrossRef] [PubMed]

74. Tahjib-Ul-Arif, M.; Roy, P.R.; Sohag, A.A.M.; Afrin, S.; Rady, M.M.; Hossain, M.A. Exogenous calcium supplementation improves salinity tolerance in BRRI dhan28; a salt-susceptible high-yielding Oryza sativa cultivar. J. Crop Sci. Biotechnol. $2018,21,383-394$. [CrossRef]

75. Han, F.; Sun, M.; He, W.; Cui, X.; Pan, H.; Wang, H.; Song, F.; Lou, Y.; Zhuge, Y. Ameliorating effects of exogenous Ca ${ }^{2+}$ on foxtail millet seedlings under salt stress. Funct. Plant Biol. 2019, 46, 407-416. [CrossRef]

76. Romer, W.; Fahning, J. Uptake and utilization of phosphorus by three inbred lines of Lolium multiflorum L. and their hybrids. Z. Pflanz. Bodenkd. 1998, 161, 35-39. [CrossRef]

77. Vance, C.P.; Uhde-Stone, C.; Allan, D.L. Phosphorus acquisition and use: Critical adaptations by plants for securing a nonrenewable resource. New Phytol. 2003, 157, 423-447. [CrossRef] [PubMed]

78. Tang, X.; Mu, X.; Shao, H.; Wang, H.; Brestic, M. Global plant-responding mechanisms to salt stress: Physiological and molecular levels and implications in biotechnology. Crit. Rev. Biotechnol. 2015, 35, 425-437. [CrossRef]

79. Ahmed, M.; Khan, S.; Irfan, M.; Aslam, M.A.; Shabbir, G.; Ahmad, S.; Fahad, S.; Basir, A.; Adnan, M. Effect of phosphorus on root signaling of wheat under different water regimes. Glob. Wheat Prod. 2018, 11, 1635-1641. [CrossRef]

80. Upadhyaya, H.; Begum, L.; Dey, B.; Nath, P.; Panda, S. Impact of calcium phosphate nanoparticles on rice plant. J. Plant Sci. Phytopathol. 2017, 1,1-10. [CrossRef]

81. Rahman, A.; Nahar, K.; Hasanuzzaman, M.; Fujita, M. Calcium supplementation improves $\mathrm{Na}^{+} / \mathrm{K}^{+}$ratio, antioxidant defense and glyoxalase systems in salt-stressed rice seedlings. Front. Plant Sci. 2016, 7,609. [CrossRef]

82. Ye, Y.; Cota-Ruiz, K.; Hernández-Viezcas, J.A.; Valdés, C.; Medina-Velo, I.A.; Turley, R.S.; Peralta-Videa, J.R.; Gardea-Torresdey, J.L. Manganese nanoparticles control salinity-modulated molecular responses in Capsicum annuum L. through priming: A sustainable approach for agriculture. ACS Sustain. Chem. Eng. 2020, 8, 1427-1436. [CrossRef]

83. El-Sharkawy, M.S.; El-Beshsbeshy, T.R.; Mahmoud, E.K.; Abdelkader, N.I.; Al-Shal, R.M.; Missaoui, A.M. Response of alfalfa under salt stress to the application of potassium sulfate nanoparticles. Am. J. Plant Sci. 2017,8, 1751-1773. [CrossRef]

84. Parveen, A.-U.-H.M.; Aziz, T.; Aziz, O.; Maqsood, L. Potassium induces carbohydrates accumulation by enhancing morphophysiological and biochemical attributes in soybean under salinity. Arch. Agron. Soil Sci. 2021, 67, 946-959. [CrossRef] 
85. Zhang, X.; Zhang, W.; Lang, D.; Cui, J.; Li, Y. Silicon improves salt tolerance of Glycyrrhiza uralensis Fisch. by ameliorating osmotic and oxidative stresses and improving phytohormonal balance. Environ. Sci. Pollut. Res. 2018, 25, 25916-25932. [CrossRef]

86. Hajiboland, R.; Cheraghvareh, L. Influence of Si supplementation on growth and some physiological and biochemical parameters in salt-stressed tobacco (Nicotiana rustica L.) plants. J. Sci. Islam. Repub. Iran 2014, 25, 205-217. [CrossRef]

87. Mamnabi, S.; Nasrollahzadeh, S.; Ghassemi-Golezani, K.; Raei, Y. Improving yield-related physiological characteristics of spring rapeseed by integrated fertilizer management under water deficit conditions. Saudi J. Biol. Sci. 2020, 27, 797-804. [CrossRef] [PubMed]

88. Wang, Y.; Wang, L.; Ma, C.; Wang, K.; Hao, Y.; Chen, Q.; Mo, Y.; Rui, Y. Effects of cerium oxide on rice seedlings as affected by co-exposure of cadmium and salt. Environ. Pollut. 2019, 252, 1087-1096. [CrossRef] [PubMed]

89. Rossi, L.; Zhang, W.; Lombardini, L.; Ma, X. The impact of cerium oxide nanoparticles on the salt stress responses of Brassica napus L. Environ. Pollut. 2016, 219, 28-36. [CrossRef]

90. Avestan, S.; Ghasemnezhad, M.; Esfahani, M.; Byrt, C.S. Application of nano-silicon dioxide improves salt stress tolerance in strawberry plants. Agronomy 2019, 9, 246. [CrossRef]

91. Mozafari, A.-A.; Ghaderi, N. Grape response to salinity stress and role of iron nanoparticle and potassium silicate to mitigate salt induced damage under in vitro conditions. Physiol. Mol. Biol. Plants 2018, 24, 25-35. [CrossRef]

92. Yang, R.; Howe, J.A.; Golden, B.R. Calcium silicate slag reduces drought stress in rice (Oryza sativa L.). J. Agron. Crop Sci. 2019, 205, 353-361. [CrossRef]

93. Sadji-Ait Kaci, H.; Chaker-Haddadj, A.; Aid, F. Interactive effects of salinity and two phosphorus fertilizers on growth and grain yield of Cicer arietinum L. Acta Agric. Scand. Sect. B Soil Plant Sci. 2017, 67, 208-216. [CrossRef]

94. Liu, C.; Wang, Y.; Pan, K.; Jin, Y.; Li, W.; Zhang, L. Effects of phosphorus application on photosynthetic carbon and nitrogen metabolism, water use efficiency and growth of dwarf bamboo (Fargesia rufa) subjected to water deficit. Plant Physiol. Biochem. 2015, 96, 20-28. [CrossRef] [PubMed]

95. Farhangi-Abriz, S.; Ghassemi-Golezani, K. How can salicylic acid and jasmonic acid mitigate salt toxicity in soybean plants? Ecotoxicol. Environ. Saf. 2018, 147, 1010-1016. [CrossRef] [PubMed]

96. Liu, R.; Lal, R. Synthetic apatite nanoparticles as a phosphorus fertilizer for soybean (Glycine max). Sci. Rep. 2014, 4, 5686. [CrossRef] [PubMed] 